\title{
Pharmacological Blockade of the Cold Receptor TRPM8 Attenuates Autonomic and Behavioral Cold Defenses and Decreases Deep Body Temperature
}

\author{
M. Camila Almeida, ${ }^{1,2}$ Tamara Hew-Butler, ${ }^{1}$ Renato N. Soriano, ${ }^{1}$ Sara Rao, ${ }^{3}$ Weiya Wang, ${ }^{3}$ Judy Wang, ${ }^{3}$ Nuria Tamayo, ${ }^{4}$ \\ Daniela L. Oliveira, ${ }^{1}$ Tatiane B. Nucci, ${ }^{1}$ Prafulla Aryal, ${ }^{5}$ Andras Garami, ${ }^{1}$ Diana Bautista, ${ }^{5}$ Narender R. Gavva, ${ }^{3}$ \\ and Andrej A. Romanovsky ${ }^{1}$ \\ ${ }^{1}$ Systemic Inflammation Laboratory (FeverLab), Trauma Research, St. Joseph's Hospital and Medical Center, Phoenix, Arizona 85013, ${ }^{2}$ Natural and \\ Humanities Sciences Center, Federal University of ABC, Santo André, SP 09210-170, Brazil, Departments of ${ }^{3}$ Neuroscience and ${ }^{4}$ Chemistry Research and \\ Discovery, Amgen, Thousand Oaks, California 91320, and ${ }^{5}$ Department of Molecular and Cell Biology, University of California, Berkeley, California 94720
}

We studied $N$-(2-aminoethyl)- $N$-(4-(benzyloxy)-3-methoxybenzyl)thiophene-2-carboxamide hydrochloride (M8-B), a selective and potent antagonist of the transient receptor potential melastatin-8 (TRPM8) channel. In vitro, M8-B blocked cold-induced and TRPM8agonist-induced activation of rat, human, and murine TRPM8 channels, including those on primary sensory neurons. In vivo, M8-B decreased deep body temperature $\left(\mathrm{T}_{\mathrm{b}}\right)$ in $\operatorname{Trpm} 8^{+/+}$mice and rats, but not in $\operatorname{Trpm} 8^{-/-}$mice, thus suggesting an on-target action. Intravenous administration of M8-B was more effective in decreasing $\mathrm{T}_{\mathrm{b}}$ in rats than intrathecal or intracerebroventricular administration, indicating a peripheral action. M8-B attenuated cold-induced c-Fos expression in the lateral parabrachial nucleus, thus indicating a site of action within the cutaneous cooling neural pathway to thermoeffectors, presumably on sensory neurons. A low intravenous dose of M8-B did not affect $\mathrm{T}_{b}$ at either a constantly high or a constantly low ambient temperature $\left(\mathrm{T}_{\mathrm{a}}\right)$, but the same dose readily decreased $\mathrm{T}_{\mathrm{b}}$ if rats were kept at a high $\mathrm{T}_{\mathrm{a}}$ during the M8-B infusion and transferred to a low $\mathrm{T}_{\mathrm{a}}$ immediately thereafter. These data suggest that both a successful delivery of M8-B to the skin (high cutaneous perfusion) and the activation of cutaneous TRPM8 channels (by cold) are required for the hypothermic action of M8-B. At tail-skin temperatures $<23^{\circ} \mathrm{C}$, the magnitude of the M8-B-induced decrease in $\mathrm{T}_{\mathrm{b}}$ was inversely related to skin temperature, thus suggesting that M8-B blocks thermal (cold) activation of TRPM8. M8-B affected all thermoeffectors studied (thermopreferendum, tail-skin vasoconstriction, and brown fat thermogenesis), thus suggesting that TRPM8 is a universal cold receptor in the thermoregulation system.

\section{Introduction}

Decreasing deep body temperature $\left(\mathrm{T}_{\mathrm{b}}\right)$ can prolong life (Conti et al., 2006) and be life saving in many diseases. Mild therapeutic hypothermia is an effective treatment in cardiac arrest, neonatal

Received Nov. 7, 2011; accepted Dec. 14, 2011.

Author contributions: M.C.A., N.T., D.B., N.R.G., and A.A.R. designed research; M.C.A., T.H.-B., R.N.S., S.R., W.W., J.W., N.T., D.L.O., T.B.N., P.A., A.G., and D.B. performed research; M.C.A., T.H.-B., R.N.S., S.R., W.W., J.W., D.L.O., T.B.N., P.A., A.G., D.B., N.R.G., and A.A.R. analyzed data; M.C.A., R.N.S., N.T., D.B., N.R.G., and A.A.R. wrote the paper.

This work was supported by study agreements with Amgen (A.A.R.), National Institutes of Health Grants R01NS41233 (A.A.R.) and R01AR059385 (D.B.), and the São Paulo State Research Support Foundation Fellowship 07/50902-0 (R.N.S.). We thank Peter Wettenstein for engineering assistance with the thermogradient studies; Gustavo M. B. Souza for histological assistance; Kenneth D. Wild, James J. J. Treanor, and Mark H. Norman for their support for the antagonist development project; Nancy L. Romanovsky for graphics assistance; and Catherine M. Krall for editing this manuscript. R.N.S. was on leave from the Department of Physiology, Medical School of Ribeirão Preto, University of São Paulo, Ribeirão Preto, SP 14049-900, Brazil. A.G. was on leave from the Department of Pathophysiology and Gerontology, Medical School, University of Pécs, Pécs, H-7624, Hungary.

S.R., W.W., J.W., N.T., and N.R.G. are employed by Amgen. A.A.R. has consulted for Amgen and TRP programs at several other pharmaceutical companies, and his TRP-related research has been supported by Amgen and Abbott Laboratories.

Correspondence should be addressed to Andrej A. Romanovsky, St. Joseph's Hospital, 350 West Thomas Road, Phoenix, AZ 85013. E-mail: aromano@chw.edu.

T.H.-B.'s present address: Exercise Science Program, School of Health Sciences, Oakland University, Rochester, Michigan 48309.

DOI:10.1523/JNEUROSCI.5606-11.2012

Copyright $\odot 2012$ the authors $\quad 0270-6474 / 12 / 322086-14 \$ 15.00 / 0$ encephalopathy, and possibly in stroke and other conditions (Bernard et al., 2002; Shankaran et al., 2005; van der Worp and van Gijn, 2007). Induction of hypothermia in an unanesthetized patient requires neutralizing the body's powerful thermoregulation system, which resists attempts of physical cooling by mounting cold defenses, or thermoeffector responses. These defenses, both physiological [such as vasoconstriction in the skin, thermogenesis in brown adipose tissue (BAT), and shivering] and behavioral (such as selection of a warmer environment), are connected via a common control variable, $\mathrm{T}_{\mathrm{b}}$ (Romanovsky, 2007; McAllen et al., 2010; Werner, 2010). If one effector mechanism is neutralized, allowing $\mathrm{T}_{\mathrm{b}}$ to decrease, the decreased $\mathrm{T}_{\mathrm{b}}$ triggers the remaining cold-defense mechanisms. Another reason why it is difficult to inactivate cold defenses is that they use multiple processes occurring in different tissues and controlled by separate pathways (Romanovsky, 2007; Nakamura and Morrison, 2008; Romanovsky et al., 2009; McAllen et al., 2010). However, all thermoeffector responses are driven by signals from thermoreceptors. Hence, the most physiological way to prevent cold-defense responses would be to block cold signals at the thermoreceptor level.

The molecular nature of innocuous thermoreception is largely unknown. A list of candidates for peripheral thermoreceptors is 
emerging and includes several temperature-sensitive transient receptor potential (TRP) channels expressed in primary sensory neurons (Lumpkin and Caterina, 2007; Talavera et al., 2008; Mishra et al., 2011). One of these channels is TRP melastatin-8 (TRPM8), also known as the cold and menthol receptor-1. In vitro, TRPM8 is activated by moderate cold (with a $22-27^{\circ} \mathrm{C}$ threshold) and exogenous "cooling-mimetic" compounds, such as menthol and icilin (McKemy et al., 2002; Peier et al., 2002). In vivo, an involvement of TRPM 8 in the selection of ambient temperature $\left(\mathrm{T}_{\mathrm{a}}\right)$ has been suggested by experiments showing that intravenous or topical (epidermal) menthol increases the preference for a warmer environment in rats and mice (Almeida et al., 2006; Tajino et al., 2007). Studies in Trpm $8^{-1-}$ mice have shown definitively that TRPM8 channels are involved in the avoidance of innocuous ambient cold (Bautista et al., 2007; Colburn et al., 2007; Dhaka et al., 2007), but it is unknown whether this involvement is strong enough to affect deep $\mathrm{T}_{\mathrm{b}}$. This question could be answered in experiments using genetic deletion or pharmacological blockade of TRPM8 channels. A study by Bautista et al. (2007) reported that $\operatorname{Trpm} 8^{-/-}$mice had the same basal $\mathrm{T}_{\mathrm{b}}$ as their wild-type littermates, but no study using $\operatorname{Tr} p m 8^{-1-}$ mice has investigated $\mathrm{T}_{\mathrm{b}}$ under different thermal conditions. Until recently, selective pharmacological tools to block the TRPM8 channel did not exist. In the present report, we used a selective and potent TRPM8 antagonist to study the involvement of the cold receptor TRPM8 in behavioral and autonomic thermoregulation and, specifically, to answer the question of whether pharmacological blockade of TRPM8 can be used to decrease $\mathrm{T}_{\mathrm{b}}$.

\section{Materials and Methods}

\section{Synthesis of compound M8-B}

We used $N$-(2-aminoethyl)- $N$-(4-(benzyloxy)-3-methoxybenzyl)thiophene-2-carboxamide hydrochloride (see Fig. $1 \mathrm{~A}$ ), a compound that we called M8-B. We synthesized M8-B according to Lampe et al. (2006), with modifications as follows.

Step 1. Potassium carbonate $(171.0 \mathrm{mmol})$ and potassium iodide $(34.5$ mmol) were added to a solution of 4-hydroxy-3-methoxybenzaldehyde $(34.2 \mathrm{mmol})$ and 1-(bromomethyl)benzene $(37.8 \mathrm{mmol})$ in acetonitrile $(200 \mathrm{ml})$. The reaction mixture was heated at $90^{\circ} \mathrm{C}$ for $3 \mathrm{~h}$ and allowed to cool to room temperature. The solvent was eliminated under a vacuum, and the residue was partitioned between water $(200 \mathrm{ml})$ and ethyl acetate $(200 \mathrm{ml})$. The layers were separated, and the aqueous phase was extracted with ethyl acetate $(2 \times 100 \mathrm{ml})$. The combined ethyl acetate phases were washed with brine, dehydrated with sodium sulfate, and concentrated in vacuo. The crude product was purified by silica gel column chromatography $(0-50 \%$ ethyl acetate in hexanes gradient). At the end of this step, we obtained $33.6 \mathrm{mmol}$ ( $98 \%$ reaction yield) of 4-(benzyloxy)-3-methoxybenzaldehyde [Intermediary 1; mass spectrum (MS; electrospray ionization [ESI], positive ion) $\mathrm{m} / \mathrm{z}, 243$ $(\mathrm{M}+1) ;{ }^{1} \mathrm{H}$ nuclear magnetic resonance (NMR; $\left.300 \mathrm{MHz}, \mathrm{CDCl}_{3}\right) \delta, 3.95(\mathrm{~s}$, $3 \mathrm{H}), 5.25(\mathrm{~s}, 2 \mathrm{H}), 6.99(\mathrm{~d}, J=8.18 \mathrm{~Hz} ; 1 \mathrm{H}), 7.29-7.50(\mathrm{~m}, 7 \mathrm{H}), 9.84(\mathrm{~s}, 1 \mathrm{H})]$.

Step 2. Sodium borohydride $(162.0 \mathrm{mmol})$ was added portionwise to a cold $\left(0^{\circ} \mathrm{C}\right)$ solution of Intermediary $1(32.6 \mathrm{mmol})$ and tert-butyl 2aminoethylcarbamate $(35.9 \mathrm{mmol})$ in methanol $(200 \mathrm{ml})$. The reaction mixture was allowed to react at room temperature under constant stirring for $1 \mathrm{~h}$. The solvent was eliminated under a vacuum, and the residue partitioned between water $(200 \mathrm{ml})$ and dichloromethane $(150 \mathrm{ml})$. The layers were separated, and the aqueous phase was extracted with dichloromethane (50 $\mathrm{ml}$ ). The combined organic phases were washed with brine and dehydrated with sodium sulfate. The residue obtained after in vacuo evaporation of the solvent contained $32.6 \mathrm{mmol}$ (quantitative reaction yield) of tert-butyl 2-(4(benzyloxy)-3-methoxybenzylamino)ethylcarbamate [Intermediary 2; MS (ESI, positive ion) $\mathrm{m} / \mathrm{z}, 387(\mathrm{M}+1) ;{ }^{1} \mathrm{H} \mathrm{NMR}\left(300 \mathrm{MHz}, \mathrm{CDCl}_{3}\right) \delta, 1.44(\mathrm{~s}$, $9 \mathrm{H}), 2.74(\mathrm{t}, J=5.92 \mathrm{~Hz}, 2 \mathrm{H}), 3.23(\mathrm{q}, J=5.70 \mathrm{~Hz}, 2 \mathrm{H}), 3.71(\mathrm{~s}, 2 \mathrm{H}), 3.90(\mathrm{~s}$, $3 \mathrm{H}), 4.91$ (br. s., $1 \mathrm{H}), 5.14$ (s, $2 \mathrm{H}), 5.29$ (s, $1 \mathrm{H}), 6.76(\mathrm{dd}, J=8.48,2.63 \mathrm{~Hz}$, $1 \mathrm{H}), 6.83(\mathrm{~d}, J=7.89 \mathrm{~Hz}, 1 \mathrm{H}), 6.89(\mathrm{~d}, J=1.75 \mathrm{~Hz}, 1 \mathrm{H}), 7.28-7.40(\mathrm{~m}, 3 \mathrm{H})$, $7.40-7.48(\mathrm{~m}, 2 \mathrm{H})]$.
Step 3. Thiophene 2-carbonyl chloride $(30.4 \mathrm{mmol})$ was added to a solution of Intermediary $2(27.6 \mathrm{mmol})$ and triethylamine $(71.9 \mathrm{mmol})$ in dichloromethane $(400 \mathrm{ml})$. The reaction mixture was allowed to react at room temperature under constant stirring for $2 \mathrm{~h}$. After the reaction mixture was concentrated in vacuo to reduce the volume by half $(200 \mathrm{ml})$, water $(200 \mathrm{ml})$ was added. The layers were separated, and the aqueous phase was extracted with dichloromethane $(2 \times 100 \mathrm{ml})$. The combined organic phases were washed with brine, dehydrated with sodium sulfate, and concentrated in vacuo. The crude product was purified by silica gel column chromatography ( $10-60 \%$ ethyl acetate in hexanes gradient). At the end of this step, we obtained $23.2 \mathrm{mmol}$ (84\% reaction yield) of tert-butyl 2-( $N$-(4-(benzyloxy)-3-methoxybenzyl)thiophene-2-carboxamido)ethylcarbamate [Intermediary 3; MS (ESI, positive ion) $\mathrm{m} / \mathrm{z}$, $497(\mathrm{M}+1) ;{ }^{1} \mathrm{H}$ NMR $\left(300 \mathrm{MHz}, \mathrm{CDCl}_{3}\right) \delta, 1.42(\mathrm{~s}, 9 \mathrm{H}), 3.38(\mathrm{q}, J=$ $5.70 \mathrm{~Hz}, 2 \mathrm{H}), 3.60(\mathrm{t}, J=6.14 \mathrm{~Hz}, 2 \mathrm{H}), 3.87(\mathrm{~s}, 3 \mathrm{H}), 4.77(\mathrm{~s}, 2 \mathrm{H}), 5.01$ (br. $\mathrm{s}, 1 \mathrm{H}), 5.15(\mathrm{~s}, 2 \mathrm{H}), 6.71-6.82(\mathrm{~m}, 2 \mathrm{H}), 6.87(\mathrm{~d}, J=7.89 \mathrm{~Hz}, 1 \mathrm{H}), 6.98$ (dd, $J=4.75,3.87 \mathrm{~Hz}, 1 \mathrm{H}), 7.27-7.40(\mathrm{~m}, 4 \mathrm{H}), 7.41-7.48(\mathrm{~m}, 3 \mathrm{H})]$.

Step 4. Hydrogen chloride ( $4 \mathrm{~N}$ in dioxane, $100 \mathrm{ml}$ ) was added to a solution of Intermediary $3(22.5 \mathrm{mmol})$ in dioxane $(100 \mathrm{ml})$. The reaction mixture was allowed to react at room temperature under constant stirring for $16 \mathrm{~h}$. The white precipitate obtained was filtered off, washed with ether, and dried in vacuo to yield $20.3 \mathrm{mmol}$ ( $90 \%$ reaction yield) of the final product, compound M8-B: $N$-(2-aminoethyl)- $N$-(4-(benzyloxy)-3-methoxybenzyl)thiophene-2-carboxamide hydrochloride [MS (ESI positive ion) $\mathrm{m} / \mathrm{z}, 397(\mathrm{M}+$ 1); ${ }^{1} \mathrm{H}$ NMR (300 MHz, DMSO- $\left.d_{6}\right) \delta, 2.96-3.11(\mathrm{~m}, 2 \mathrm{H}), 3.55-3.68(\mathrm{~m}$, 2H), $3.76(\mathrm{~s}, 3 \mathrm{H}), 4.73(\mathrm{~s}, 2 \mathrm{H}), 5.07(\mathrm{~s}, 2 \mathrm{H}), 6.77(\mathrm{~d}, J=8.04 \mathrm{~Hz}, 1 \mathrm{H}), 6.89$ (br. s., $1 \mathrm{H}), 7.05(\mathrm{~d}, J=8.33 \mathrm{~Hz}, 1 \mathrm{H}), 7.10(\mathrm{dd}, J=4.97,3.80 \mathrm{~Hz}, 1 \mathrm{H})$, 7.23-7.54 (m, 6H), 7.78 (dd, $J=5.04,0.95 \mathrm{~Hz}, 1 \mathrm{H}), 8.07$ (br. s., $2 \mathrm{H}$ )].

\section{Characterization of the pharmacological profile of M8-B}

Stable Chinese hamster ovary cell lines expressing TRPM8 or TRP ankyrin-1 (TRPA1), vanilloid-1 (TRPV1), vanilloid-3 (TRPV3), or vanilloid-4 (TRPV4) were generated using the tetracycline-inducible T-REx system from Invitrogen. To enable luminescence readout based on intracellular increase in $\mathrm{Ca}^{2+}$ (Le Poul et al., 2002), each cell line was also cotransfected with a pcDNA3.1 plasmid containing jellyfish aequorin cDNA. Twenty-four hours before the assay, cells were seeded in 96-well plates, and TRP channel expression was induced by tetracycline $(0.5 \mu \mathrm{g} / \mathrm{ml})$. On the day of the assay, culture media were removed, and cells were incubated for $2 \mathrm{~h}$ with assay buffer (Ham's F-12 containing 30 mM HEPES for TRPA1, TRPM8, and TRPV3; Ham's F-12 containing 30 mM HEPES, $1 \mathrm{~mm} \mathrm{CaCl}_{2}$, and $0.3 \%$ bovine serum albumin for TRPV4) that contained $15 \mu \mathrm{M}$ coelenterazine (PJK). Antagonists were added 2.5 min before addition of an agonist. The luminescence was measured by a charge-coupled device camera based on a FLASH luminometer built by Amgen. The following TRP antagonists were used: ruthenium red for TRPA1 $\left(\mathrm{IC}_{50}=367 \mathrm{~nm}\right)$ and TRPV4 $\left(\mathrm{IC}_{50}=24 \mathrm{nM}\right)$, AMG9810 for TRPV1 $\left(\mathrm{IC}_{50}=86 \mathrm{nM}\right)$, and compound V3-H for TRPV3 $\left(\mathrm{IC}_{50}=72\right.$ $\mathrm{nM}$ ). The following TRP agonists were used: $80 \mu \mathrm{M}$ allylisothiocyanate for TRPA1, $1 \mu \mathrm{M}$ icilin and $100 \mu \mathrm{M}$ menthol for TRPM8, $500 \mathrm{~mm}$ capsaicin for TRPV1, $200 \mu \mathrm{M}$ 2-APB for TRPV3, and $1 \mu \mathrm{M} 4 \alpha$-phorbol-12, 13didecanoate for TRPV4. Compound activity was calculated using Prism 4.01 (GraphPad Software). A cooling device attached to the FLASH luminometer was used for cold $\left(10^{\circ} \mathrm{C}\right)$ activation of TRPM8. Capsaicininduced ${ }^{45} \mathrm{Ca}^{2+}$ uptake was used for evaluating the antagonistic activity of compound M8-B against the TRPV1 channel, as reported previously (Gavva et al., 2005). The selectivity assays were conducted as reported previously (Lehto et al., 2008).

Trigeminal or dorsal root ganglion neurons were isolated from mouse pups ( 0 to $14 \mathrm{~d}$ old). Preparation of neurons and ratiometric $\mathrm{Ca}^{2+}$ imaging were carried out as described previously (Bautista et al. 2007). Briefly, neurons from sensory ganglia were dissected and incubated for $10 \mathrm{~min}$ in $1.4 \mathrm{mg} / \mathrm{ml}$ Collagenase P (Roche) in calcium-free HBSS [University of California, San Francisco (UCSF) Cell Culture Facility]. Neurons were then incubated in $0.25 \%$ trypsin, versene-EDTA solution (UCSF) for $3 \mathrm{~min}$ with gentle agitation. Cells were washed and then triturated and plated in media (Eagle's MEM with EBSS medium, supplemented with $10 \%$ horse serum, MEM vitamins, penicillin/streptomycin, and L-glutamine; all reagents were purchased from UCSF Cell 
Culture Facility). Neurons were plated onto glass coverslips and used within $20 \mathrm{~h}$. For calcium imaging experiments, cells were loaded for $1 \mathrm{~h}$ with $10 \mu \mathrm{M}$ fura-2 AM (Invitrogen), supplemented with $0.01 \%$ Pluronic F-127 (Invitrogen), in a physiological Ringer solution, $\mathrm{pH}$ 7.4, containing the following (in mM): $140 \mathrm{NaCl}, 5 \mathrm{KCl}, 10 \mathrm{HEPES}, 2 \mathrm{CaCl}_{2}, 2 \mathrm{MgCl}_{2}$, and $10 \mathrm{D}-(+)$-glucose (all chemicals were purchased from SigmaAdrich). Acquired images were displayed as the ratio of 340 to $380 \mathrm{~nm}$ and aligned using MetaMorph software (Molecular Devices). Cells were identified as neurons by eliciting depolarization with high potassium solution $(150 \mathrm{~mm})$ at the end of each experiment. Neurons were deemed to be sensitive to cold or a cooling mimetic if the mean ratio during the $10 \mathrm{~s}$ after stimulus application was $\geq 15 \%$ above baseline.

\section{Animals}

The experiments were conducted in mice and rats under protocols approved by the St. Joseph's Hospital and Medical Center Animal Care and Use Committee. Male C57BL/6 mice were purchased from Charles River Laboratories. Trpm8-deficient $\left(\operatorname{Tr} p m 8^{-/-}\right)$mice on the C57BL/6 background were obtained from the University of California, Berkeley (Bautista et al., 2007). Male Wistar rats were purchased from Harlan. At the time of the experiments, mice weighed 25-35 g, and rats weighed $300-$ $350 \mathrm{~g}$. All animals were housed in cages kept in temperature-controlled units $\left(\mathrm{T}_{\mathrm{a}}\right.$ of $27-28^{\circ} \mathrm{C}$ ) and under a $12 \mathrm{~h}$ light/dark cycle (lights on at 6:00 A.M.). Standard laboratory rodent chow and tap water were available $\mathrm{ad}$ libitum. All mice were extensively habituated for experiments in the telemetry setup, in which they wore harnesses (Covance Infusion Harness; Instech Laboratories) and moved freely inside Plexiglas enclosures. Rats were extensively habituated to experiments in the thermocouple or respirometry setup (where they stayed in cylindrical wire mesh confiners) or in the thermogradient setup (in which they freely moved inside the channels of the thermogradient apparatus).

\section{Surgery}

Anesthesia. For all surgeries, animals were anesthetized by ketaminexylazine-acepromazine (mice, 81.7, 9.3, and $1.2 \mathrm{mg} / \mathrm{kg}$, i.p.; rats, 55.6, 5.5 , and $1.1 \mathrm{mg} / \mathrm{kg}$, i.p., respectively) and received an antibiotic (enrofloxacin, $1.1 \mathrm{mg} / \mathrm{kg}$, s.c.) prophylactically. During surgery, the anesthetized animals were kept on a heating pad. The abdomens of rats assigned to experiments with epidermal application of menthol were shaved. Mice were periodically (every $5 \mathrm{~min}$ ) ventilated with oxygen through custommade masks. To prevent postsurgical hypothermia, mice were allowed to recover from anesthesia in an environmental chamber set to a $\mathrm{T}_{\mathrm{a}}$ of $31^{\circ} \mathrm{C}$. (the $\mathrm{T}_{\mathrm{a}}$ in the chamber was always set to the first decimal place, e.g., $31.0^{\circ} \mathrm{C}$, but all $\mathrm{T}_{\mathrm{a}}$ values are reported in this paper with no decimal places for brevity). All procedures were performed 5-7 d before an experiment. Each mouse or rat was subjected to one or more of the surgical procedures described below.

Implantation of temperature-measuring devices. Each mouse was implanted with a miniature telemetry transmitter (G2 E-Mitter series; Mini Mitter) to monitor the abdominal temperature (a measure of deep $\mathrm{T}_{\mathrm{b}}$ ) in the telemetry setup. Each rat designated for an experiment in the thermogradient setup was implanted with a miniature temperature data logger (SubCue Dataloggers) to record abdominal temperature in this setup. Either type of temperature-measuring device was implanted into the peritoneal cavity via a midline laparotomy and fixed to the left lateral abdominal wall with sutures. The abdominal muscles and skin were sutured in layers.

Preparation for BAT thermometry. In rats designated for experiments that involved measuring BAT temperature $\left(\mathrm{T}_{\mathrm{BAT}}\right)$, a guide cannula for a thermocouple was implanted under the pads of interscapular BAT. A longitudinal incision was made through the skin and subcutaneous tissue on the dorsal surface of the body in the interscapular area, along the midline. A polyethylene (PE)-160 guide cannula was passed under the BAT pads in the rostral direction along the midline. The guide cannula had a sealed end and an inside stopper (located $10 \mathrm{~mm}$ from the sealed end). The stopper determined the position of the thermocouple tip when a thermocouple was inserted into the guide cannula during experiments. The cannula was positioned along the vertebral column in a way that the stopper was in a close proximity to Sulzer's vein, which drains blood from the BAT pads. The cannula was then secured in place with ligatures, and its open (caudal) end was exteriorized on the back. The surgical wound was closed with clips. After experiments, the location of the cannula was verified postmortem.

Intraperitoneal catheterization. This procedure was performed in mice only. Following a small midline incision, a PE-50 catheter filled with pyrogen-free saline was inserted into the peritoneal cavity and fixed to the right abdominal wall with a suture. The free end of the catheter was heat closed, tunneled under the skin to the nape of the neck, and exteriorized. The surgical wound was sutured. The catheter was flushed with saline on the day after surgery and every other day thereafter.

Intravenous catheterization. This and all procedures described below were performed in rats only. A small longitudinal incision was made on the ventral surface of the neck, left of the trachea. The left jugular vein was exposed, freed from its surrounding connective tissue, and ligated. A silicone catheter (inner diameter, $0.5 \mathrm{~mm}$; outer diameter, $0.9 \mathrm{~mm}$ ) filled with heparinized $(10 \mathrm{U} / \mathrm{ml})$ saline was passed into the superior vena cava through the jugular vein and secured in place with ligatures. The free end of the catheter was knotted, tunneled under the skin to the nape of the neck, and exteriorized. The wound was sutured. The catheter was flushed with heparinized saline $(10 \mathrm{U} / \mathrm{ml})$ daily.

Intracerebroventricular cannulation. Each rat was fixed to a stereotaxic apparatus (David Kopf Instruments) with the incisor bar set $3.3 \mathrm{~mm}$ ventral to the interaural line. The scalp was incised over the sagittal suture, the periosteum was excised, four supporting microscrews were driven into the skull, and a small hole was drilled in the skull $0.8 \mathrm{~mm}$ posterior to bregma and $1.5 \mathrm{~mm}$ lateral to the midline. A 22 gauge steel guide cannula (Plastics One) was fitted onto a piece of 28 gauge stainlesssteel wire, so that the wire ended flush with the tip of the cannula. The other end of the wire was fixed into a manipulator used to insert the cannula into the brain through the bone hole. The tip of the cannula was placed just dorsal to the roof of the right lateral ventricle $(2.5 \mathrm{~mm}$ from the skull surface). The cannula was secured to the supporting microscrews with acrylic cement and released from the manipulator. A 28 gauge stylet ("dummy injector," Plastics One) was inserted into the guide cannula.

Intrathecal catheterization. This procedure was performed as detailed previously (Pogatzki et al., 2000). Briefly, each rat was placed in a kyphotic position, and the skin on the back was incised along the midline at the level of the iliac crests. The space between lumbar vertebrae 5 and 6 was punctured with a 23 gauge hypodermic needle, which was pushed in until it reached the thecal space. Penetration into the thecal space was associated with a tail flick or hind paw retraction. A 32 ga polyurethane catheter reinforced with a steel stylet (Micor) was passed through the hypodermic needle into the thecal space and advanced rostrally by 4.0 $\mathrm{cm}$. The stylet and needle were removed, and the exterior end of the catheter was bound to a PE-50 catheter using Scotch-Weld structural plastic adhesive (DP-8010;3M). After the adhesive cured for $20 \mathrm{~min}$, the free end of the catheter was heat closed and exteriorized at the nape. The incised skin was sutured.

\section{Experimental setups}

Four experimental setups were used: telemetric thermometry in an environmental chamber (telemetry setup), thermocouple thermometry in an environmental chamber (thermocouple setup), thermocouple thermometry and respirometry in an environmental chamber (respirometry setup), and abdominal temperature recording with an implanted temperature data logger in a thermogradient apparatus (thermogradient setup). Mice and rats were studied in these setups at several different ambient temperatures (Table 1).

Telemetry setup. Mice, inside their home cages, were studied in the telemetry setup. Telemetry receivers (model ER-4000; Mini Mitter) were positioned in a climatic chamber (model 3940; Forma Scientific), and cages were placed on top of the receivers. After each mouse was equipped with a Covance Infusion Harness (Instech Laboratories), the intravenous catheter was extended with a length of PE-50 tubing filled with the drug of interest or vehicle. The mouse was placed into a Plexiglas enclosure inside of the cage, and the extension tubing was passed through a protective steel coil and attached to the bottom of a stainless-steel swivel (model 
Table 1. Ambient temperatures used in different experimental setups and their relationship to the midpoint of the thermoneutral zone

\begin{tabular}{|c|c|c|c|}
\hline Experimental setup & Species & Ambient temperatures used in this study & Midpoint of thermoneutral zone (references) \\
\hline \multirow[t]{3}{*}{ Telemetry } & \multirow[t]{3}{*}{ Mouse } & \multirow[t]{3}{*}{$26^{\circ} \mathrm{C}$ (subneutral) } & $>31^{\circ} \mathrm{C}$ (Rudaya et al., 2005) \\
\hline & & & $32^{\circ} \mathrm{C}$ (Garami et al., 2011) \\
\hline & & & $\begin{array}{l}34^{\circ} \mathrm{C} \text { (A. Garami and A. A. Romanovsky, } \\
\text { unpublished observations) }\end{array}$ \\
\hline Thermocouple & Rat & $4,11,14,15,19,21$, and $24^{\circ} \mathrm{C}$ (subneutral); 28 and $32^{\circ} \mathrm{C}$ (near neutral) & $30^{\circ} \mathrm{C}$ (Romanovsky et al., 2002) \\
\hline Respirometry & Rat & $19^{\circ} \mathrm{C}$ (subneutral) & $26^{\circ} \mathrm{C}$ (Steiner et al., 2007) \\
\hline Thermogradient & Rat & Freely selected between 15 and $30^{\circ} \mathrm{C}$ (subneutral to supraneutral) & $24^{\circ} \mathrm{C}$ (Almeida et al., 2006) \\
\hline
\end{tabular}

375/22; Instech Laboratories). The swivel was positioned on a counterbalance arm (model SMCLA; Instech Laboratories) mounted on the top of the Plexiglas enclosure. The ends of the protective coil were attached to the harness and the swivel. Another PE-50 extension filled with saline was connected to the top of the swivel, passed through a port in the chamber wall, and connected to the infusion syringe located outside of the chamber.

Thermocouple setup. After each rat was equipped with copper-constantan thermocouples (Omega Engineering) to measure deep $\mathrm{T}_{\mathrm{b}}$ (colonic), tail-skin temperature $\left(\mathrm{T}_{\mathrm{sk}}\right)$, and $\mathrm{T}_{\mathrm{BAT}}$ (in a subset of experiments), it was placed in a confiner. The colonic thermocouple was inserted $10 \mathrm{~cm}$ beyond the anal sphincter and fixed to the base of the tail with a loop of adhesive tape. The skin thermocouple was positioned on the lateral surface of the tail (at the boundary of the proximal and middle thirds) and insulated from the environment with tape. The BAT thermocouple was inserted into the preimplanted guide cannula up to the stopper and fixed in place with tape. Thermocouples were plugged into a data logger (Cole-Parmer). Each rat in a confiner was placed inside a climatic chamber (Forma Scientific). The venous catheter was connected to a PE-50 extension filled with the drug of interest. The extension was then passed through a port of the chamber and connected to a syringe. The air temperature in the chamber was set to $11,14,15,19,21,24,28$, or $32^{\circ} \mathrm{C}$. In a set of experiments, rats were infused with a drug in an environmental chamber set to one temperature and then rapidly transferred to another chamber set to a different temperature.

Respirometry setup. Rats were equipped with copper-constantan thermocouples for recording colonic $\mathrm{T}_{\mathrm{b}}$ and $\mathrm{T}_{\mathrm{sk}}$, as in the thermocouple setup. Each rat in a confiner was then placed inside a cylindrical Plexiglas chamber (Sable Systems), which was sealed and continuously ventilated. The airflow was maintained at $600 \mathrm{ml} / \mathrm{min}$ (standard conditions for temperature and pressure) with the aid of a mass flow controller (Sierra Instruments). Air leaving each chamber was automatically sampled, dried, and passed through an oxygen analyzer (Sable Systems). The Plexiglas chamber containing the rat was housed inside a climatic chamber (Forma Scientific). When present, the catheter (venous or thecal) was connected to a PE-50 extension filled with the drug or vehicle. When the animal had an intracerebroventricular cannula, a needle injector was fitted into the guide cannula and connected to a PE-50 extension. The extension (from the catheter or intracerebroventricular injector) was passed through a port of the Plexiglas chamber, and the port was sealed with paraffin. The extension was then passed through a port of the climatic chamber and connected to a syringe placed in an infusion pump (model 220; KD Scientific).

Thermogradient setup. The thermogradient apparatus used was described in detail previously (Almeida et al., 2006). The apparatus consisted of six 200-cm-long aluminum channels. Each channel had a second (inner) stainless-steel grid floor and an acrylic double wall lid at the top. At each end, all channels shared a common aluminum wall, which separated the channels from a large tank. The tank at the "warm" end of the channels was filled with water heated by two electric units (PolyScience) to maintain air temperature inside the channels at this end at $30.0^{\circ} \mathrm{C}$. The tank at the "cold" end was constantly perfused with $10 \%$ ethylene glycol by an external-circulation cooling/heating pump (PolyScience) to maintain air temperature inside the channels at this end at $15.0^{\circ} \mathrm{C}$. In this setting, all channels had a common, nearly linear longitudinal temperature gradient of $0.075^{\circ} \mathrm{C} / \mathrm{cm}$. In each channel, the position of a rat was monitored with 56 evenly spaced $(3.5 \mathrm{~cm})$ infrared emitterreceiver pairs, which formed transversal infrared beams.<smiles>COc1cc(CN(CCN)C(=O)c2cccs2)ccc1OCc1ccccc1</smiles>
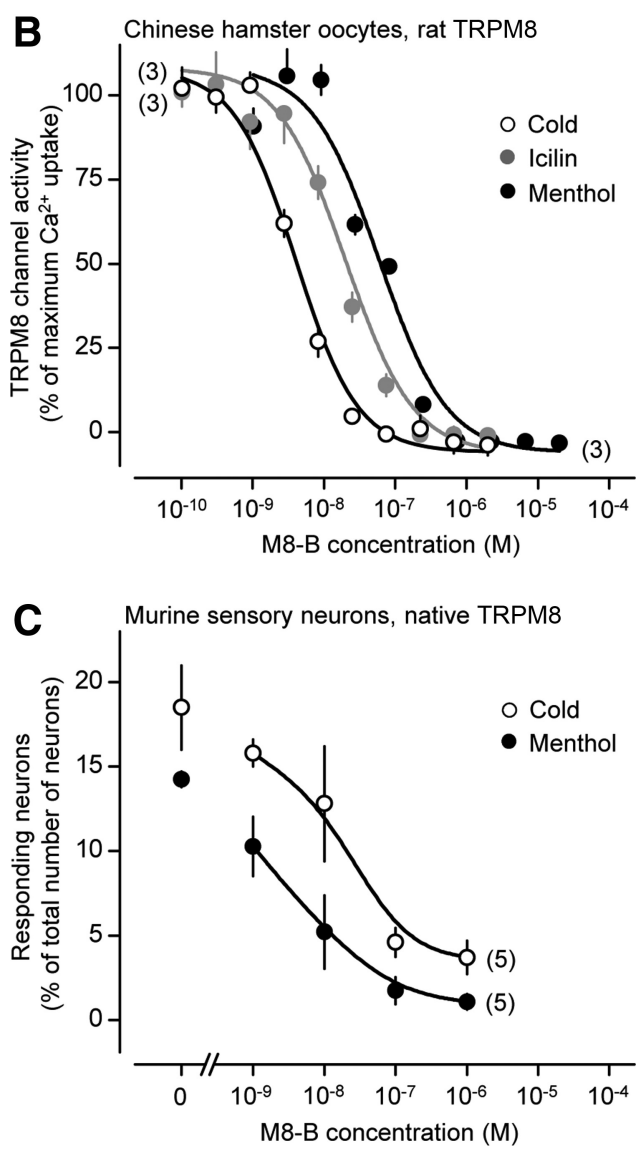

Figure 1. Chemical structure and in vitro pharmacology of M8-B. $A$, Structural formula of $M 8-B$ as confirmed by spectral analysis. $B$, Concentration-dependent effects of M8-B on the activation of rat TRPM8 channels (stably expressed in Chinese hamster ovary cells) by cold $\left(10^{\circ} \mathrm{C}\right)$, icilin $(1 \mu \mathrm{M})$, and menthol (100 $\left.\mu \mathrm{M}\right)$. C, Concentration-dependent effects of M8-B on the activation of native TRPM8 channels in murine primary sensory neurons by cold $\left(15^{\circ} \mathrm{C}\right)$ and menthol $(250 \mu \mathrm{m})$. Here and in other figures, the number of experiments is shown in parentheses at each curve.

\section{Drugs and drug administration}

Intraperitoneal resiniferatoxin to mice. Resiniferatoxin (RTX) from Euphorbia poisonii was purchased from Sigma-Aldrich. A stock solution of RTX $(20 \mathrm{mg} / \mathrm{ml})$ in $100 \%$ ethanol was prepared, aliquoted, and stored at $-80^{\circ} \mathrm{C}$. On the day of an experiment, the stock was diluted to make a working solution of RTX $(150 \mathrm{ng} / \mathrm{ml})$ in a vehicle containing $20 \%$ ethanol and $20 \%$ propylene glycol in saline. This working solution was infused $(1 \mathrm{ml} / \mathrm{kg})$ via the peritoneal catheter over a $10 \mathrm{~min}$ 
period to deliver a low dose of $150 \mathrm{ng} / \mathrm{kg}$. In contrast to high doses, e.g., $20 \mu \mathrm{g} / \mathrm{kg}$ (Steiner et al., 2011), such low doses of RTX do not require sedation.

Intraperitoneal M8-B to mice. M8-B (molar mass, $396.2 \mathrm{~g} / \mathrm{mol}$ ) was dissolved $(6 \mathrm{mg} / \mathrm{ml}$ in $20 \%$ ethanol, $20 \%$ propylene glycol in saline) on the day of the experiment. This solution was infused $(1 \mathrm{ml} / \mathrm{kg})$ via the peritoneal catheter over a $10 \mathrm{~min}$ period to deliver a dose of $6 \mathrm{mg} / \mathrm{kg}(15.2$ $\mu \mathrm{mol} / \mathrm{kg})$.

Intravenous M8-B to rats. A working solution of M8-B (3.3-19.8 mg/ $\mathrm{ml})$ in $100 \%$ ethanol was prepared ex tempore. M8-B or its vehicle $(0.3$ $\mathrm{ml} / \mathrm{kg}$ ) was slowly $(5-10 \mu \mathrm{l} / \mathrm{min})$ infused through the venous catheter to deliver a dose of $1-6 \mathrm{mg} / \mathrm{kg}(2.5-15.2 \mu \mathrm{mol} / \mathrm{kg})$. Infusion of the drug or vehicle was followed by flushing the catheter with saline. The total time of the infusion together with flushing ranged from 20 to $40 \mathrm{~min}$. Slow infusion of ethanol has been used extensively in our laboratory and shown to produce neither hemolysis nor any other signs of ethanol toxicity (Steiner et al., 2007, 2009; Garami et al., 2010).

Intracerebroventricular M8-B to rats. A working solution of M8-B (38 $\mathrm{mg} / \mathrm{ml}$ ) in $50 \%$ ethanol $/ 50 \%$ propylene glycol was prepared ex tempore. M8-B or its vehicle was slowly $(1 \mu \mathrm{l} / \mathrm{min})$ infused into the lateral brain ventricle. The infusions were performed via a 28 gauge injector needle (Plastics One) fitted into the preimplanted 22 gauge guide cannula. The injector protruded $2 \mathrm{~mm}$ beyond the end of the guide cannula (thus reaching the lateral ventricle). The injector was fitted to the guide at least $2 \mathrm{~h}$ before the infusion. The same or similar protocols have been used in our previous studies (Steiner et al., 2007; Garami et al., 2011). The total dose of M8-B delivered was $2.5 \mathrm{mg} / \mathrm{kg}(6.3 \mu \mathrm{mol} / \mathrm{kg})$.

Intrathecal M8-B to rats. A working solution of M8-B $(15$ or $38 \mathrm{mg} / \mathrm{ml})$ in $50 \%$ ethanol $/ 50 \%$ propylene glycol was prepared ex tempore. By slowly ( $2 \mu \mathrm{l} / \mathrm{min}$ ) infusing this solution via the thecal catheter, a total M8-B dose of 2.5 or $6 \mathrm{mg} / \mathrm{kg}$ ( 6.3 or $15.2 \mu \mathrm{mol} / \mathrm{kg}$ ) was delivered. Control rats were infused with vehicle. A similar protocol was used in our previous study (Steiner et al., 2007).

\section{Immunohistochemistry}

We used an immunohistochemical approach to determine whether TRPM8 antagonism alters the number of c-Fos-activated neurons in the lateral parabrachial nucleus (LPB) in cold-exposed rats. Each rat was implanted with an intravenous catheter and extensively adapted to the experimental setup to avoid a nonspecific (stress-associated) induction of c-Fos (Bachtell et al., 2003). On the day of experiment, each rat was placed in a confiner and transferred in a climatic chamber (Forma Scientific). The intravenous catheter was connected to a PE-50 extension filled with a drug or its vehicle. The extension was passed through a port of the chamber and connected to an infusion syringe. Chamber temperature was set at $32^{\circ} \mathrm{C}$. Rats were left to acclimate at this temperature and then infused with M8-B ( $1 \mathrm{mg} / \mathrm{kg}$ or $2.5 \mu \mathrm{mol} / \mathrm{kg})$ or vehicle. Immediately after infusion, rats were transferred to another climatic chamber. This second chamber was set to a temperature of either 32 or $4^{\circ} \mathrm{C}$. Rats were kept in the second chamber for $2 \mathrm{~h}$ and then deeply anesthetized and transcardially perfused with $\mathrm{PBS}$ followed by $4 \%$ paraformaldehyde, $\mathrm{pH}$ 7.4. The brains were removed, postfixed for $4 \mathrm{~h}$ in the same fixative, cryoprotected in $30 \%$ sucrose at $4^{\circ} \mathrm{C}$ for $48 \mathrm{~h}$, and sectioned $(35 \mu \mathrm{m})$ in a cryostat. Immunohistochemistry for c-Fos was performed with biotinylated anti-rabbit IgG (1:200; Vector Laboratories), avidin-biotin-peroxidase complex (Vectastain Elite ABC kit; Vector Laboratories), and diaminobenzidine (Vector Laboratories) as the developing agent. The primary antibody was rabbit anti-c-Fos antibody (1: 40,000; Calbiochem).

\section{Data processing and analysis}

For in vitro experiments, image analysis and statistics were performed using custom routines in MATLAB (MathWorks) and Igor Pro (WaveMetrics). Statistical significance was assessed by one-way ANOVA followed by Tukey's honestly significant difference test. In vivo, the heat loss index (HLI) was used as an index of tail-skin vasomotor tone. It was calculated according to the formula HLI $=\left(\mathrm{T}_{\mathrm{sk}}-\mathrm{T}_{\mathrm{a}}\right) /\left(\mathrm{T}_{\mathrm{b}}-\mathrm{T}_{\mathrm{a}}\right)($ Romanovsky et al., 2002). The thermogenesis index $\left(\mathrm{T}_{\mathrm{BAT}}-\mathrm{T}_{\mathrm{b}}\right)$ was used as an index of BAT heat production (Romanovsky et al., 1997). As in the
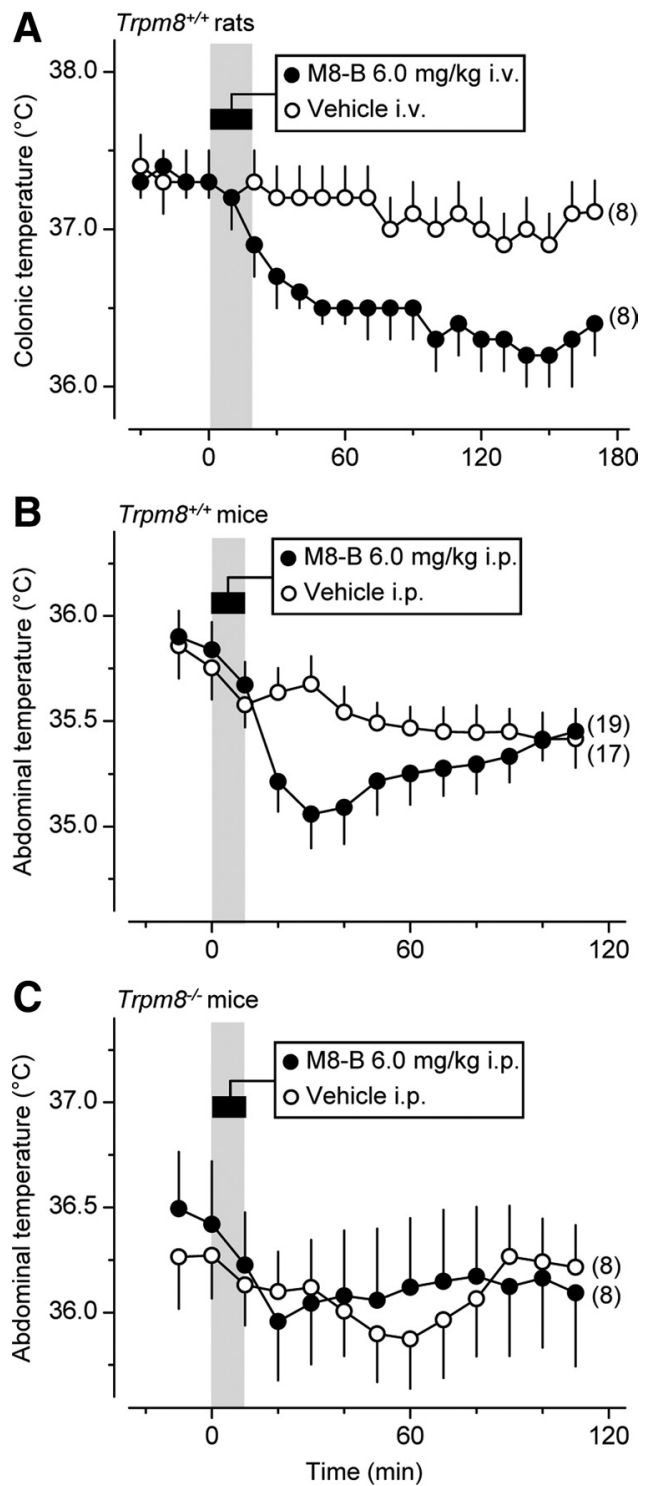

Figure 2. M8-B decreases deep $\mathrm{T}_{\mathrm{b}}$ in $T r p m 8^{+/+}$rats and mice, but not in Trpm $8^{-/-}$mice. $A-C$, The figure shows the effect of intravenous infusion of M8-B (dose indicated) or its vehicle on colonic $\mathrm{T}_{\mathrm{b}}$ in Trpm $8^{+/+}$rats $(\boldsymbol{A})$ and the effects of intraperitoneal infusion of M8-B or its vehicle on deep (abdominal) $\mathrm{T}_{\mathrm{b}}$ in $\operatorname{Trpm} 8^{+/+}$mice $(\boldsymbol{B})$ and $\operatorname{Trpm} 8^{-/-}$mice $(\boldsymbol{C})$. Experiments were conducted at a subneutral $\mathrm{T}_{\mathrm{a}}\left(19^{\circ} \mathrm{C}\right.$ for rats, $26^{\circ} \mathrm{C}$ for mice). Here and in other figures, the time of M8-B infusion is shown with a gray bar.

past (Steiner et al., 2007; Garami et al., 2011), oxygen consumption $\left(\mathrm{VO}_{2}\right)$ was used as an index of metabolic heat production. It was calculated by comparing the oxygen fraction in the air that exited a chamber containing a rat $\left(\mathrm{FO}_{2 \text {-rat }}\right)$ to the oxygen fraction in the air that exited an empty chamber $\left(\mathrm{FO}_{2 \text {-chamber }}\right)$. The following formula was used: $\mathrm{VO}_{2}=$ [air flow $\left.\times\left(F_{2 \text {-chamber }}-F_{2 \text {-rat }}\right)\right] /(1-[(1-$ respiratory quotient $) \times$ $\left.\left.\mathrm{FO}_{2 \text {-chamber }}\right]\right) /$ rat mass, where the respiratory quotient was considered to be 0.71 . The equation term that includes the respiratory quotient accounts for the fact that $\mathrm{CO}_{2}$ produced by the rat was not extracted from the air passing though the oxygen analyzer in our experimental setup. Responses were compared by one-way or two-way ANOVA followed by Bonferroni's post hoc test as appropriate, using Statistica AX'99 (StatSoft). The c-Fos-immunoreactive cell counting was performed blindly by a single examiner using Image (NIH). Numbers of c-Fospositive cells were compared using Student's $t$ test. Data are presented as the mean $\pm \mathrm{SE}$. 

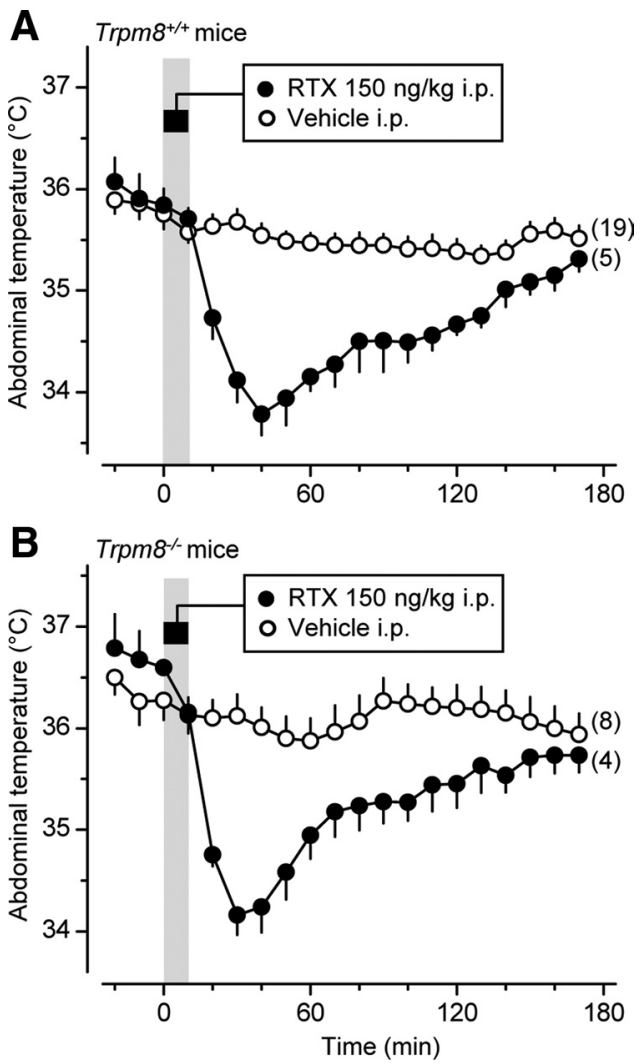

Figure 3. RTX readily produces hypothermia in both $T r p m 8^{+/+}$and $T r p m 8^{-/-}$mice. A, B, The figure shows the effects of the intraperitoneal infusion of RTX (dose indicated) or its vehicle on the deep (abdominal) $\mathrm{T}_{\mathrm{b}}$ in Trpm $8^{+/+}(\boldsymbol{A})$ and $T r p m 8^{-/-}(\boldsymbol{B})$ mice. Experiments were conducted at the subneutral $\mathrm{T}_{a}$ of $26^{\circ} \mathrm{C}$. The time of RTX infusion is shown with a gray bar.

\section{Results}

M8-B antagonizes activation of TRPM8 channels in vitro

After synthesizing M8-B (see Materials and Methods, Synthesis of compound M8-B) (Fig. 1A), we studied the ability of M8-B to block TRPM8 activation by cold $\left(10^{\circ} \mathrm{C}\right)$, icilin $(1 \mu \mathrm{M})$, or menthol $(100 \mu \mathrm{M})$ in cultured Chinese hamster ovary cells stably transfected with rat or human TRPM8 channels. M8-B inhibited activation of rat TRPM8 by cold $\left(\mathrm{IC}_{50}=7.8 \pm 1.1\right.$ $\mathrm{nM})$, icilin $\left(\mathrm{IC}_{50}=26.9 \pm 12.1 \mathrm{nM}\right)$, or menthol $\left(\mathrm{IC}_{50}=64.3 \pm\right.$ $3.4 \mathrm{~nm}$ ) in a concentration-dependent manner (Fig. $1 B$ ). M8-B also inhibited activation of human TRPM8 by cold, icilin, or menthol with similar potencies (data not shown). Importantly, M8-B was found to be selective, as it did not block other TRP channels $\left(\mathrm{IC}_{50}>20 \mu \mathrm{M}\right)$.

Next, we asked whether M8-B blocks activation of native TRPM8 channels in murine somatosensory neurons (Fig. 1C). When exposed to cold, $19 \pm 3 \%$ of neurons displayed a significant increase in cellular $\mathrm{Ca}^{2+}$ levels. Treatment with M8-B (10 $\mu \mathrm{M})$ decreased the number of cold-responsive neurons to $4 \pm 1 \%$ $(p<0.01)$, which is comparable to percentages reported previously in Trpm $8^{-1-}$ animals (Bautista et al., 2007; Colburn et al., 2007; Dhaka et al., 2007). Likewise, M8-B significantly decreased the number of neurons responsive to menthol $(250 \mu \mathrm{M})$. Together, these findings show that M8-B potently inhibits responses of rat, human, and murine TRPM8, including native TRPM8 channels on primary sensory neurons, to cold and coolingmimetic compounds.
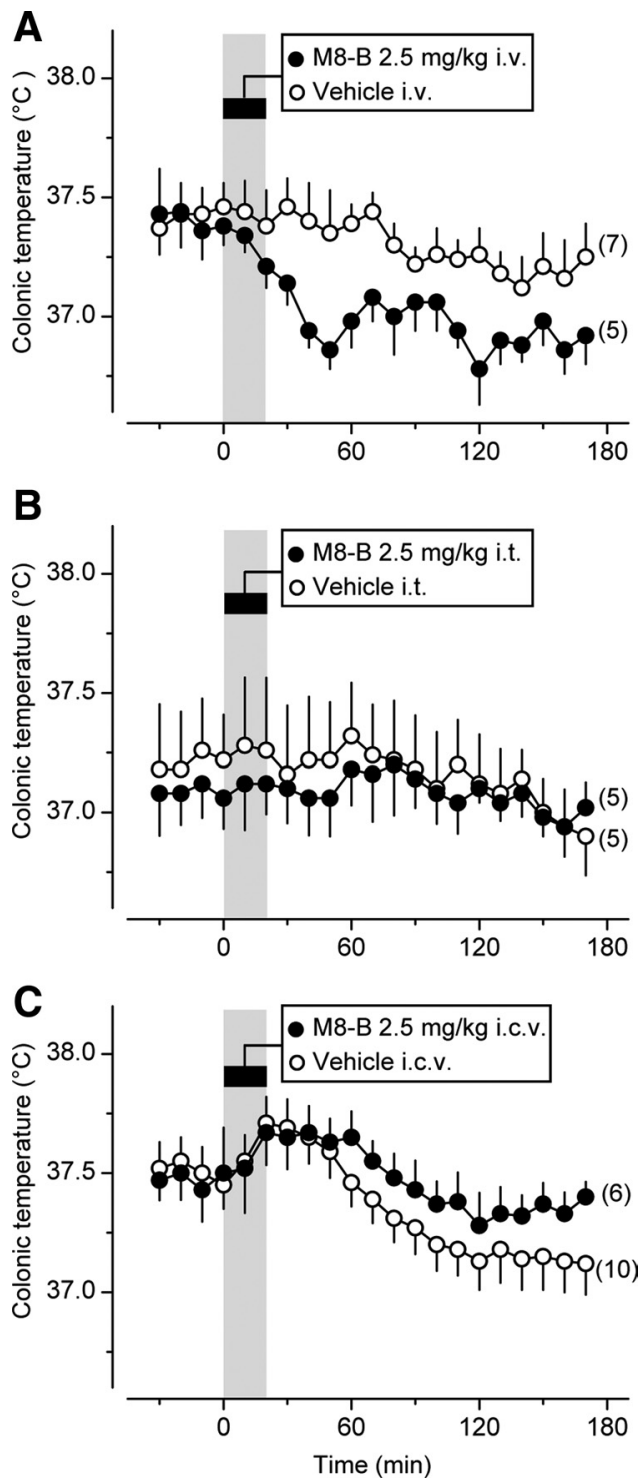

Figure 4. M8-B decreases $T_{b}$ when administered peripherally but not centrally. $A-C$, The figure shows the effects of intravenous $(\boldsymbol{A})$, intrathecal $(\boldsymbol{B})$, and intracerebroventricular $(\boldsymbol{C})$ infusion of M8-B at the same dose (indicated) or of the vehicle on colonic $T_{b}$ in rats. Experiments were conducted at a subneutral $\mathrm{T}_{\mathrm{a}}$ of $19^{\circ} \mathrm{C}$.

\section{M8-B decreases $T_{b}$ in rats and mice by acting on}

TRPM8 channels

Next, we studied the effects of M8-B on deep (colonic) $T_{b}$ in chronically prepared, conscious rats. These experiments were conducted in the thermocouple setup (see Materials and Methods, Experimental setups) at a subneutral $\mathrm{T}_{\mathrm{a}}$ of $19^{\circ} \mathrm{C}$ (Table 1). Under these conditions, intravenous infusion of $\mathrm{M} 8$ - $\mathrm{B}$ at a high dose $(6 \mathrm{mg} / \mathrm{kg})$ over $20 \mathrm{~min}$ caused a marked $\left(\sim 0.9^{\circ} \mathrm{C}\right)$ decrease in $\mathrm{T}_{\mathrm{b}}$ compared to the vehicle $(p=0.031)$ (Fig. $\left.2 A\right)$. We then studied the effects of M8-B on $\mathrm{T}_{\mathrm{b}}$ in $\operatorname{Trpm} 8^{-/-}$and $\operatorname{Trp} m 8^{+/+}$ mice in the telemetry setup. These experiments were also conducted under subneutral conditions $\left(\mathrm{T}_{\mathrm{a}}\right.$ of $\left.26^{\circ} \mathrm{C}\right)$. Like rats, the mice were infused with $\mathrm{M} 8-\mathrm{B}(6 \mathrm{mg} / \mathrm{kg})$ or its vehicle in a nonstressful manner, via a preimplanted catheter. However, to avoid technical problems associated with the catheterization of small murine veins, the catheter was implanted in the peritoneal cavity. $\operatorname{Trpm} 8^{+/+}$mice responded to M8-B, but not to its vehicle, with a marked $\left(\sim 0.8^{\circ} \mathrm{C}\right)$ decrease in abdominal $\mathrm{T}_{\mathrm{b}}(p<0.0001)$ (Fig. 
A

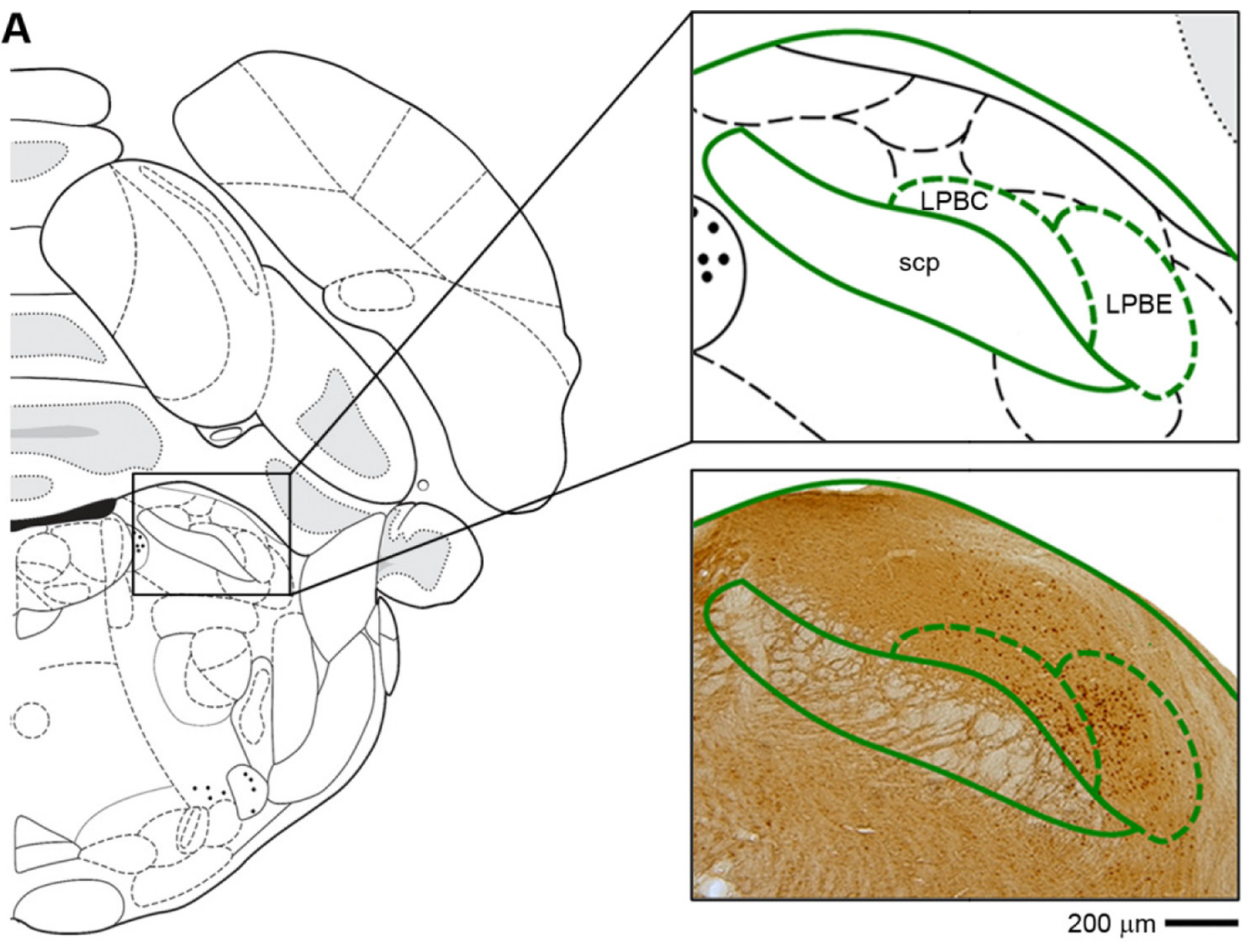

B Thermoneutral environment: $32^{\circ} \mathrm{C}$ Vehicle i.v. M8-B $1.0 \mathrm{mg} / \mathrm{kg}$ i.v.

Cold Exposure: $4^{\circ} \mathrm{C}$
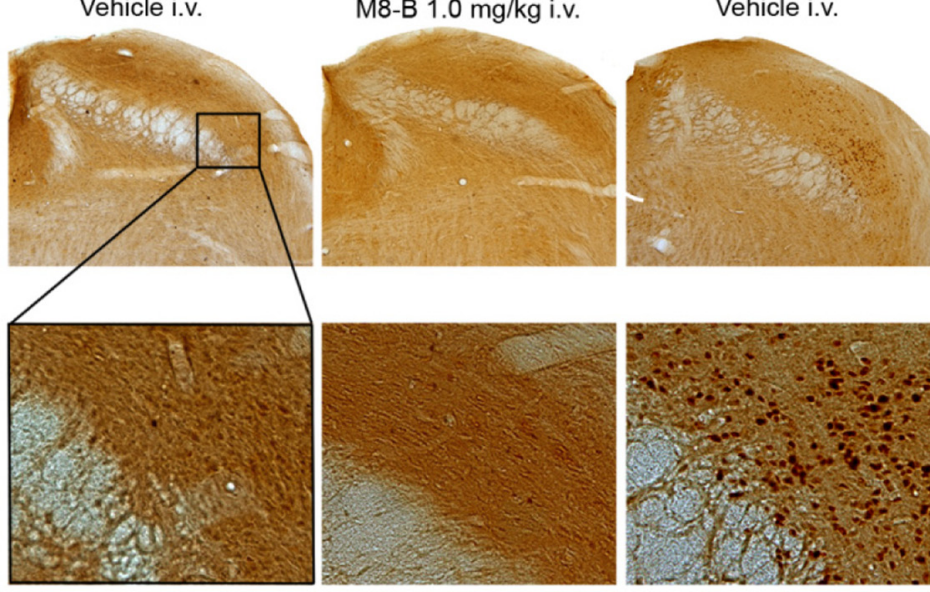

M8-B $1.0 \mathrm{mg} / \mathrm{kg}$ i.v.
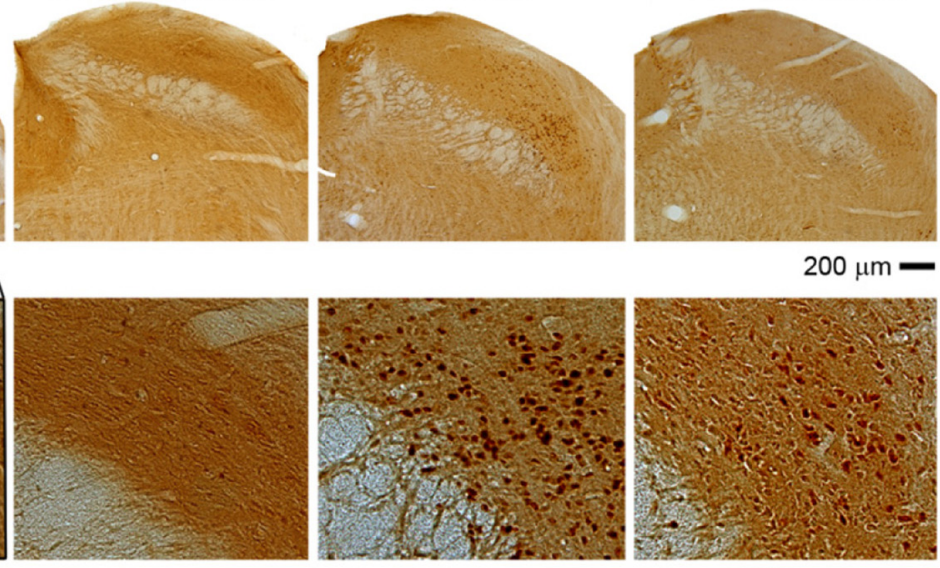

$200 \mu \mathrm{m}$
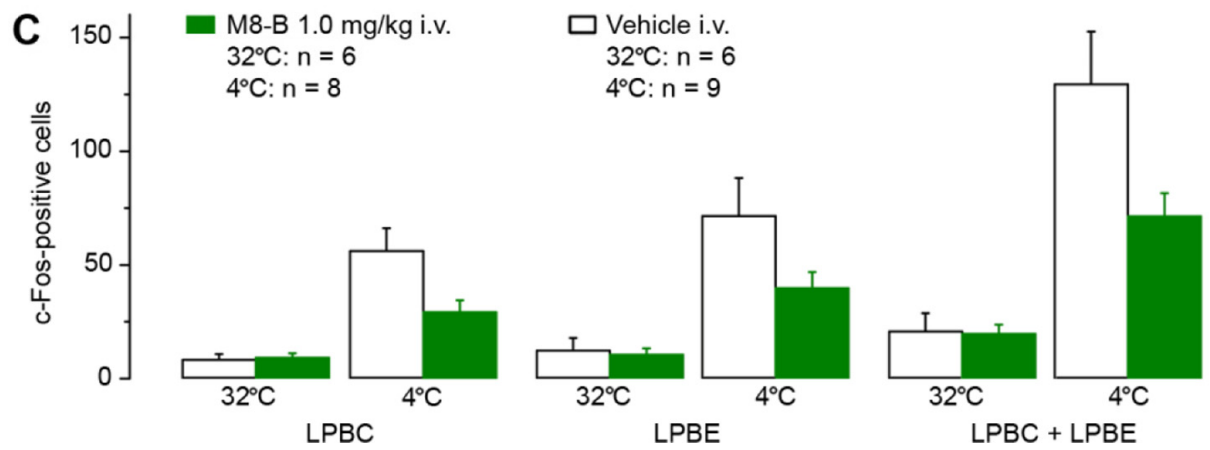

Figure 5. M8-B suppresses cold-induced c-Fos expression in the LPB. A, How borders of the LPBC and LPBE were determined for cell counting. Based on the schematic drawing of the $-9.12 \mathrm{~mm}$ coronal plane of rat brain (Paxinos and Watson, 2007), a template was made that encompassed two targeted areas (the LPBC and LPBE; dashed green line) and two landmarks [the border of the superior cerebellar peduncle (scp) and the dorsal border of the pons; solid green line]. From each animal, a pontine tissue section most representative of the $-9.12 \mathrm{~mm}$ coronal plane was selected. The template was appropriately scaled and overlapped with the tissue section to best fit the landmarks, and the number of c-Fos-positive cells within the targeted areas was counted. $\boldsymbol{B}$, Representative photomicrographs of four pontine sections containing c-Fos-positive neurons. The sections were obtained from rats treated with M8-B or its vehicle and exposed to either a warm $\left(32^{\circ} \mathrm{C}\right)$ or cold $\left(4^{\circ} \mathrm{C}\right)$ environment. C, Quantitative analyses of C-Fos-immunoreactive cells in the LPBC and LPBE, separately (left, middle) and together (right). 

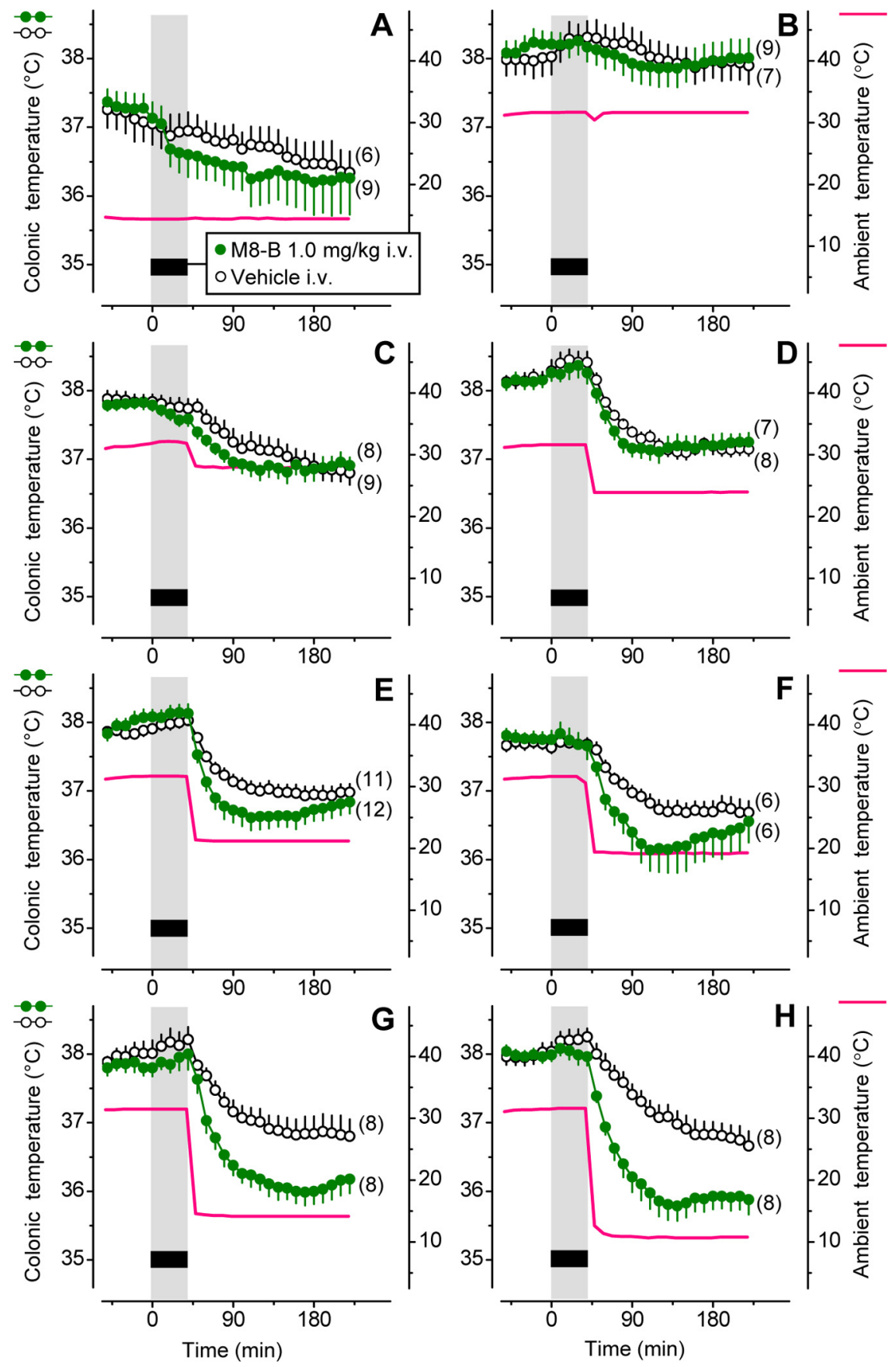

Figure 6. The thermoregulatory effect of M8-B strongly depends on $T_{\mathrm{a}}$. The figure shows the effect of intravenous infusion of $M 8-B$ or its vehicle on colonic $T_{b}$ in rats. The rats were kept in an environmental chamber before and during the infusion and transferred to another environmental chamber immediately after the infusion. $\boldsymbol{A}-\boldsymbol{H}$, The first chamber had an ambient temperature set to either a deep subneutral level of $15^{\circ} \mathrm{C}(\boldsymbol{A})$ or a supraneutral level of $32^{\circ} \mathrm{C}(\boldsymbol{B}-\boldsymbol{H})$. The second chamber had $\mathrm{T}_{\mathrm{a}}$ set to $15^{\circ} \mathrm{C}$ $(\boldsymbol{A}), 32^{\circ} \mathrm{C}(\boldsymbol{B}), 28^{\circ} \mathrm{C}(\boldsymbol{C}), 24^{\circ} \mathrm{C}(\boldsymbol{D}), 21^{\circ} \mathrm{C}(\boldsymbol{E}), 19^{\circ} \mathrm{C}(\boldsymbol{F}), 14^{\circ} \mathrm{C}(\boldsymbol{G})$, or $11^{\circ} \mathrm{C}(\boldsymbol{H})$. The mean $\mathrm{T}_{\mathrm{a}}$ to which the animals were exposed in each experiment is shown with a red line. Note that small SE values for $\mathrm{T}_{\mathrm{a}}\left(<0.1^{\circ} \mathrm{C}\right)$ make SE bars invisible.

rats and mice and that it causes the hypothermic effect by acting on TRPM8 channels.

\section{M8-B decreases $T_{b}$ by acting peripherally}

We then asked whether M8-B decreases $\mathrm{T}_{\mathrm{b}}$ by acting inside or outside the CNS. These experiments were conducted in rats placed in the thermocouple setup, at a $\mathrm{T}_{\mathrm{a}}$ of $19^{\circ} \mathrm{C}$. We found that the intravenous dose of $1 \mathrm{mg} / \mathrm{kg}$ did not affect $\mathrm{T}_{\mathrm{b}}$ under these (data not shown) or similar (see Fig. $6 A, B)$ conditions. The threshold intravenous dose of M8-B for causing a significant $(p=0.04)$ decrease in deep $\mathrm{T}_{\mathrm{b}}$ was $2.5 \mathrm{mg} / \mathrm{kg}$ (Fig. 4A). The $2.5 \mathrm{mg} / \mathrm{kg}$ dose had no effect on $\mathrm{T}_{\mathrm{b}}$ in rats when administered either intrathecally (Fig. $4 B$ ) or intracerebroventricularly (Fig. 4C). These data clearly show that M8-B decreases $\mathrm{T}_{\mathrm{b}}$ by blocking TRPM8 channels outside of the CNS. Experiments with a higher dose of M8-B (6 mg/kg) further support this conclusion. Indeed, the 6 $\mathrm{mg} / \mathrm{kg}$ dose was effective in decreasing $\mathrm{T}_{\mathrm{b}}$ when administered either intrathecally or intravenously, but neither the magnitude nor duration of the response to intrathecal administration exceeded the corresponding characteristic of the response to intravenous administration.

\section{M8-B acts within the cutaneous cold-activated neural pathway}

Knowing that M8-B acts peripherally, and that TRPM8 channels are expressed in dorsal-root and trigeminal neurons (Peier et al., 2002; Takashima et al., 2007), we hypothesized that M8-B decreases $\mathrm{T}_{\mathrm{b}}$ by blocking activation of TRPM8 channels localized in the skin, on primary sensory neurons within the cutaneous coolingactivated neural pathway for control of physiological thermoeffectors (Nakamura and Morrison, 2008). To test this hypothesis, we measured expression of the inducible transcription factor c-Fos, a marker of neuronal activation (Sagar et al., 1988), in the LPB, specifically in its external (LPBE) and central (LPBC) subnuclei (Fig. 5A). Neurons in these subnuclei receive cutaneous cold signals from primary sensory neurons (Cechetto et al.,

$2 B$ ). In contrast, the abdominal $\mathrm{T}_{\mathrm{b}}$ of $\operatorname{Trpm} 8^{-/-}$mice was not affected by M8-B (Fig. 2C). Importantly, the absence of response in Trpm $8^{-1-}$ mice to M8-B was not due to their inability to develop hypothermia. When the same mice were treated with the TRPV1 agonist RTX (150 ng/kg, i.p.) at the same $\mathrm{T}_{\mathrm{a}}$ of $26^{\circ} \mathrm{C}$ to cause TRPM8-independent hypothermia, they responded to this treatment with a profound $\left(\sim 2.5^{\circ} \mathrm{C}\right)$ decrease in $\mathrm{T}_{\mathrm{b}}(p<0.0001)$, which was similar to the hypothermic response of $\operatorname{Trp} m 8^{+/+}$ mice (Fig. 3). These data show that systemic M8-B decreases $T_{b}$ in
1985; Feil and Herbert, 1995; Nakamura and Morrison, 2008) and transmit these signals to the preoptic hypothalamus (Bratincsak et al., 2008; Nakamura and Morrison, 2008). In agreement with previous reports (Bratincsak and Palkovits, 2004; Nakamura and Morrison, 2008), the $2 \mathrm{~h}$ cold exposure $\left(4^{\circ} \mathrm{C}\right)$ used in the present study induced c-Fos immunoreactivity expression in the LPBE and LPBC ( $p=0.003$ and $p=0.001$, respectively) of vehicle-pretreated rats. Cold exposure also induced a small in- 
crease in the number of c-Fos-positive neurons in the crescent area of the LPB (data not shown), but not in the dorsal or internal area. Pretreatment with a high (6 $\mathrm{mg} / \mathrm{kg}$, i.v.) dose of M8-B attenuated the cold-induced expression of c-Fos: the number of c-Fos-positive neurons was decreased in the LPBC (by 41\%; $p=0.178$ ), LPBE (by $48 \% ; p=0.027$ ), and the two subnuclei combined (by $45 \% ; p=0.012$ ). These data show that the target of M8-B is located within the skin cooling-activated neural pathway, upstream of LPB neurons. Taking into account that M8-B acts peripherally, and that there is only one peripheral neuron located upstream of the LPB in this pathway (the primary coldsensitive neuron innervating the skin), our data point to cutaneous primary sensory neurons as the site of hypothermic action of M8-B. This conclusion agrees with our finding that M8-B potently blocks activation of primary sensory neurons by cold in vitro (Fig. 1C).

\section{M8-B decreases $T_{b}$ when it has access to the skin and when cutaneous cold receptors are activated}

If the conclusion that M8-B causes hypothermia by acting on sensory neurons is correct, M8-B would need to have access to the skin to decrease $T_{b}$. To test this hypothesis, we conducted eight physiological experiments with a low $(1 \mathrm{mg} / \mathrm{kg})$ intravenous dose of M8-B administered at different levels of skin blood flow and different levels of cutaneous cold stimulation (Fig. 6). In the first two experiments, $\mathrm{T}_{\mathrm{a}}$ was kept at a constant level: either $15^{\circ} \mathrm{C}$, which is below the thermoneutral zone (Fig. $6 \mathrm{~A}$ ), or $32^{\circ} \mathrm{C}$, which is at the upper border of the thermoneutral zone (Fig. $6 \mathrm{~B}$ ). At either $\mathrm{T}_{\mathrm{a}}$, intravenous infusion of the low dose of M8-B caused no significant changes in $\mathrm{T}_{\mathrm{b}}$ compared to the vehicle. At $32^{\circ} \mathrm{C}$, the skin of rats is strongly vasodilated in this experimental setup (Romanovsky et al., 2002), and the antagonist was likely delivered to the skin with high blood flow. However, cold sensors in the skin exposed to the high $\mathrm{T}_{\mathrm{a}}$ of $32^{\circ} \mathrm{C}$ and perfused with even warmer blood were not likely to be activated, because TRPM8 activation in vitro occurs only at temperatures $<22-27^{\circ} \mathrm{C}$ ( McKemy et al., 2002; Peier et al., 2002). On the other hand, TRPM8 channels were presumably activated when rats were exposed to the low $\mathrm{T}_{\mathrm{a}}$ of $15^{\circ} \mathrm{C}$, but blood flow through the skin was minimal under these conditions, as rats already develop full cutaneous vasoconstriction at a substantially higher $\left(\sim 27^{\circ} \mathrm{C}\right) \mathrm{T}_{\mathrm{a}}$ (Romanovsky et al., 2002). Hence, M8-B presumably might not have been delivered to TRPM8 channels on skin sensory neurons in this experiment.

To test the hypothetic explanation outlined above, we changed $\mathrm{T}_{\mathrm{a}}$ in a stepwise fashion in the next six experiments. First, we infused the same low dose of M8-B (or vehicle) in rats at $\mathrm{T}_{\mathrm{a}}$ of $32^{\circ} \mathrm{C}$ (thus promoting drug delivery to cutaneous receptors). Then, as soon as the infusion ended, we transferred the rats to another climatic chamber, which was set to a different $\mathrm{T}_{\mathrm{a}}: 28,24$, $21,19,14$, or $11^{\circ} \mathrm{C}$ (Fig. $6 \mathrm{C}-\mathrm{H}$ ). As the $\mathrm{T}_{\mathrm{a}}$ used in the second chamber decreased, M8-B-treated rats started to exhibit a drop in $\mathrm{T}_{\mathrm{b}}$ compared to vehicle-treated controls. At a $\mathrm{T}_{\mathrm{a}}$ of $14^{\circ} \mathrm{C}$ (Fig. $6 \mathrm{G}$ ) or $11^{\circ} \mathrm{C}$ (Fig. $6 \mathrm{H}$ ), the intertreatment $\mathrm{T}_{\mathrm{b}}$ differ- ence exceeded $1^{\circ} \mathrm{C}$ and was statistically significant $(p=0.01$ and $p=0.003$, respectively). These results agree with the hypothesis that both a successful delivery of the antagonist to the skin (with high cutaneous blood flow) and the activation of cutaneous TRPM8 receptors (by cold) are required for the hypothermic response to the low dose of intravenous M8-B. These results also agree with our conclusion from the peripheral versus ventral administration experiment and from the c-Fos experiment: M8-B causes hypothermia by acting on peripherally located sensory neurons within the cutaneous cooling-activated neural pathway to autonomic thermoeffectors.

\section{M8-B decreases $\mathrm{T}_{\mathrm{b}}$ by blocking thermal (cold) activation of TRPM8}

We then analyzed the relationship between $\mathrm{T}_{\mathrm{b}}$ response and M8-B (Fig. $6 B-H$ ) and mean tail $\mathrm{T}_{\mathrm{sk}}$ during this response. To evaluate $\mathrm{T}_{\mathrm{b}}$ response to $\mathrm{M} 8 \mathrm{-B}$, we calculated the hypothermic response as a time ( $50-240 \mathrm{~min}$ ) integral of the $\mathrm{M} 8$-B-induced $\mathrm{T}_{\mathrm{b}}$ decrease. This index is commonly known as the "area under the curve" (or in this case, above the curve). By using a two-line model, we found that M8-B caused a decrease in $T_{b}$ when tail $T_{\text {sk }}$ was $\leq 23.2^{\circ} \mathrm{C}$ (Fig. 7). Below this threshold, the hypothermic response index depended linearly on $\mathrm{T}_{\text {sk }}\left(r^{2}=0.85 ; p=0.025\right)$, thus suggesting that M8-B causes hypothermia by blocking thermal (cold) activation of TRPM8 channels. A lack of dependence would suggest that the antagonist caused the response by blocking nonthermal activation of M8-B. For example, the TRPV1 antagonist AMG0347 has been shown to cause hyperthermia by blocking activation of TRPV1 channels caused by protons and chemical ligands, but not by temperature (Garami et al., 2010). Accordingly, no positive correlation was found in our previous study (Steiner et al., 2007) between the magnitude of the thermal response to AMG0347 and any measured temperature $\left(\mathrm{T}_{\mathrm{sk}}, \mathrm{T}_{\mathrm{a}}\right.$, or $\mathrm{T}_{\mathrm{b}}$ ). In contrast, the strong relationship reported here between M8-B-induced hypothermia and intensity of cutaneous cold 

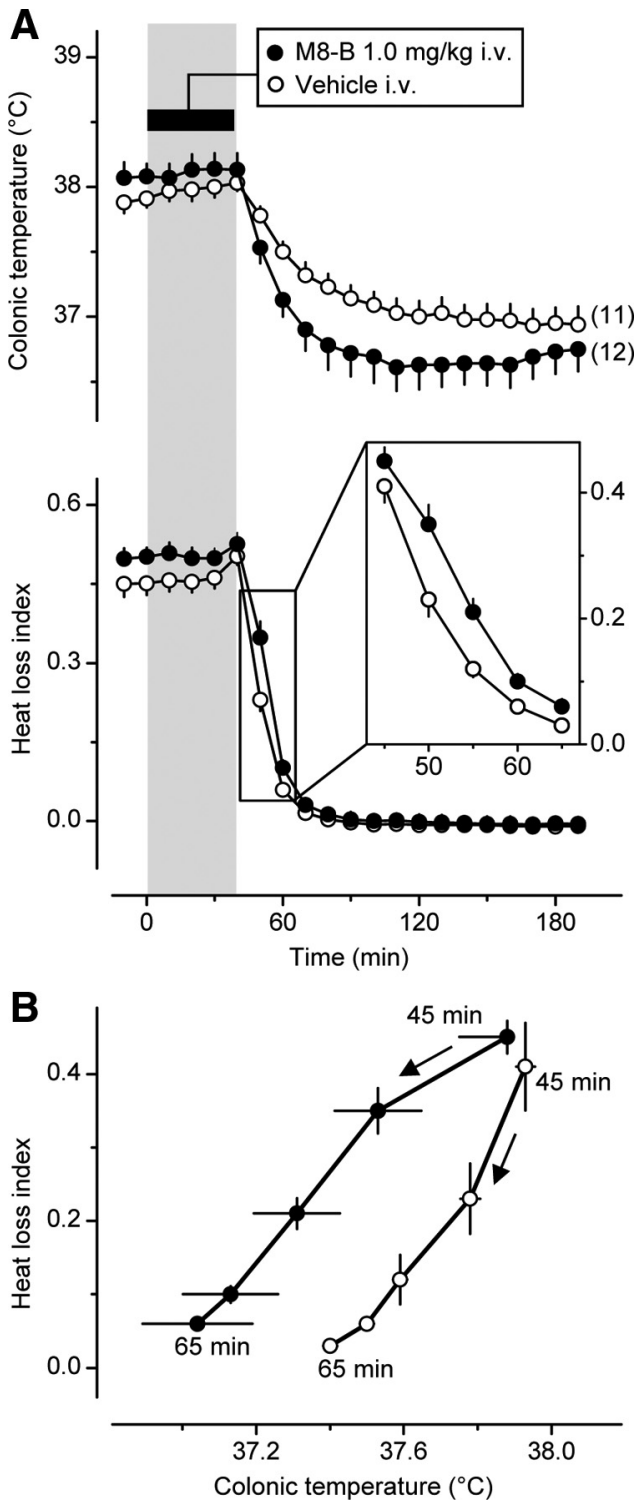

Figure 8. M8-B delay onset of the tail-skin vasoconstrictor response to a cold environment. $A$, Changes in colonic $\mathrm{T}_{b}$ and $\mathrm{HLl}$ in rats transferred to a cool environment $\left(21^{\circ} \mathrm{C}\right.$ ) after intravenous infusion of M8-B or its vehicle in a warm environment $\left(32^{\circ} \mathrm{C}\right)$. The transfer took place immediately after the end of infusion (at $45 \mathrm{~min}$ ). $\boldsymbol{B}$, Relationships between $\mathrm{HLI}$ and $\mathrm{T}_{\mathrm{b}}$ in M8-B-treated and vehicle-treated rats at onset of the hypothermic response (45- $65 \mathrm{~min}$ ). Here and in Figures $9 B, 10 B$, and $11 B$, the direction of time is shown with arrows, and the times corresponding to the earliest and latest data points are indicated.

stimulation suggests that M8-B causes hypothermia by blocking thermal (cold) activation of TRPM8 channels.

\section{M8-B affects the regulation of tail-skin vasomotor tone}

Because peripheral thermoreception and central thermoreception likely involve different molecules (Zhao and Boulant, 2005; Boulant, 2006), and because different thermoeffectors are likely controlled by different combinations of core and shell temperatures (Romanovsky, 2007; Romanovsky et al., 2009), the contributions of different TRP channels to the regulation of different thermoeffectors may differ. For example, activation of TRPV1 channels in the abdominal viscera suppresses BAT thermogenesis and tail-skin vasoconstriction in rats, but does not seem to affect selection of $\mathrm{T}_{\mathrm{a}}$ (Steiner et al., 2007). By running experiments in different setups and varying the dose of $M 8-B$ and $T_{a}$, we asked
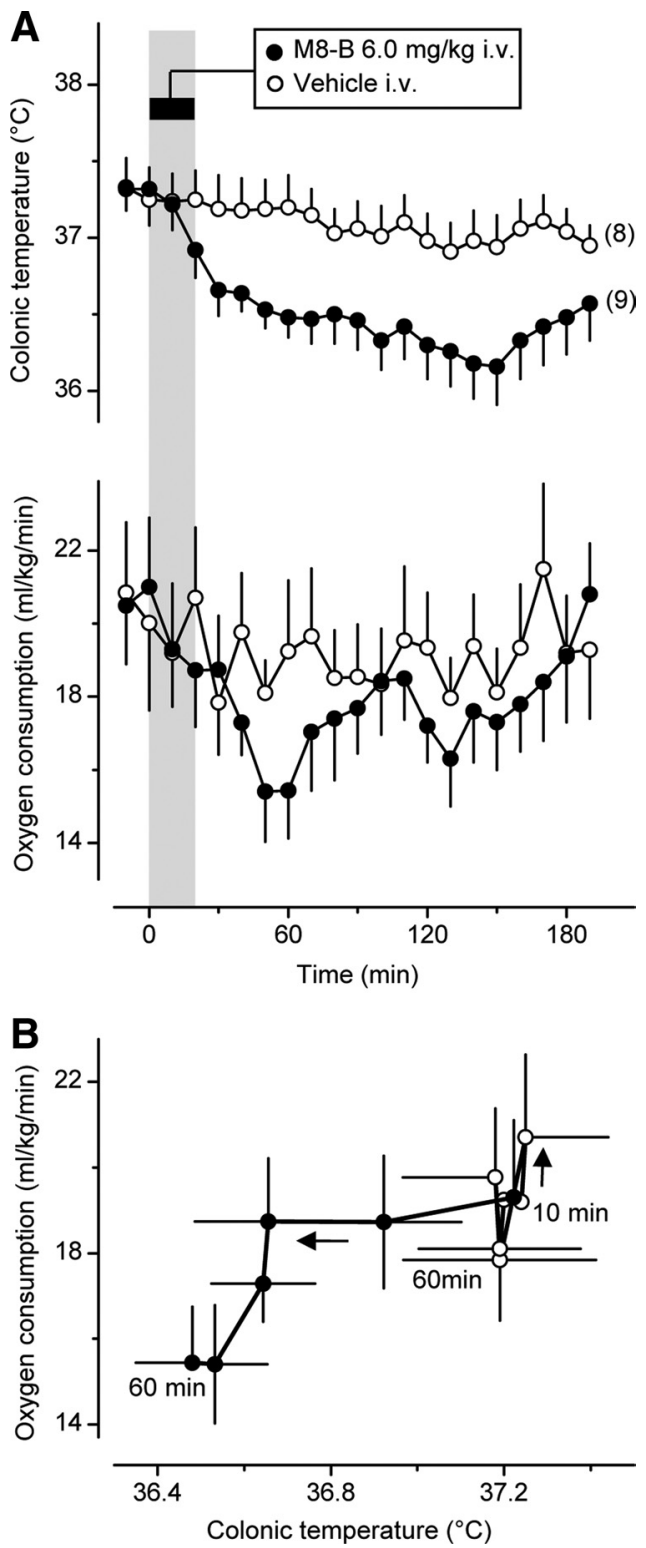

Figure 9. Thermogenesis is inhibited at onset of the $T_{b}$ response to a high dose of M8-B at a constant subneutral $\mathrm{T}_{\mathrm{a}} \cdot \boldsymbol{A}$, Changes in colonic $\mathrm{T}_{\mathrm{b}}$ and $\mathrm{VO}_{2}$ in response to intravenous infusion of $M 8-B$ or its vehicle in a cool environment $\left(19^{\circ} \mathrm{C}\right) . B$, Relationships between $V O_{2}$ and $T_{b}$ at onset of the hypothermic response $(10-60 \mathrm{~min})$ in M8-B-treated and vehicle-treated rats.

whether we could find experimental conditions under which an involvement of a given thermoeffector in the hypothermic response of rats to M8-B could be demonstrated convincingly.

To test whether tail-skin vasodilation could be recruited for the $\mathrm{T}_{\mathrm{b}}$ response to $\mathrm{M} 8-\mathrm{B}$, we used the thermocouple setup and recorded colonic $\mathrm{T}_{\mathrm{b}}$, tail $\mathrm{T}_{\mathrm{sk}}$, and $\mathrm{T}_{\mathrm{a}}$ in rats. Rats were infused with the low dose of M8-B ( $1 \mathrm{mg} / \mathrm{kg}$, i.v.) or vehicle over 40 min at an ambient temperature of $32^{\circ} \mathrm{C}$ and then transferred to $21^{\circ} \mathrm{C}$ (as in Fig. $6 \mathrm{E}$ ). Although lowering $\mathrm{T}_{\mathrm{a}}$ to $<21^{\circ} \mathrm{C}$ for the second part of this experiment would have resulted in a greater drop in $\mathrm{T}_{\mathrm{b}}$ (as in Fig. $6 \mathrm{~F}-\mathrm{H}$ ), a drug rarely causes tail-skin vasodilation in a colder environment (Romanovsky et al., 1996). Even at $21^{\circ} \mathrm{C}, \mathrm{M} 8-\mathrm{B}$ produced a significant decrease in $\mathrm{T}_{\mathrm{b}}(p=0.0001)$ (Fig. $\left.8 \mathrm{~A}\right)$. Before and during infusion (i.e., when rats were exposed to $32^{\circ} \mathrm{C}$ ), both $\mathrm{M} 8$-B-treated and vehicle-treated rats exhibited tail vasodilation, as evident from the high $(\sim 0.5)$ values of the HLI, a $\mathrm{T}_{\text {sk }}$-based measure of skin 

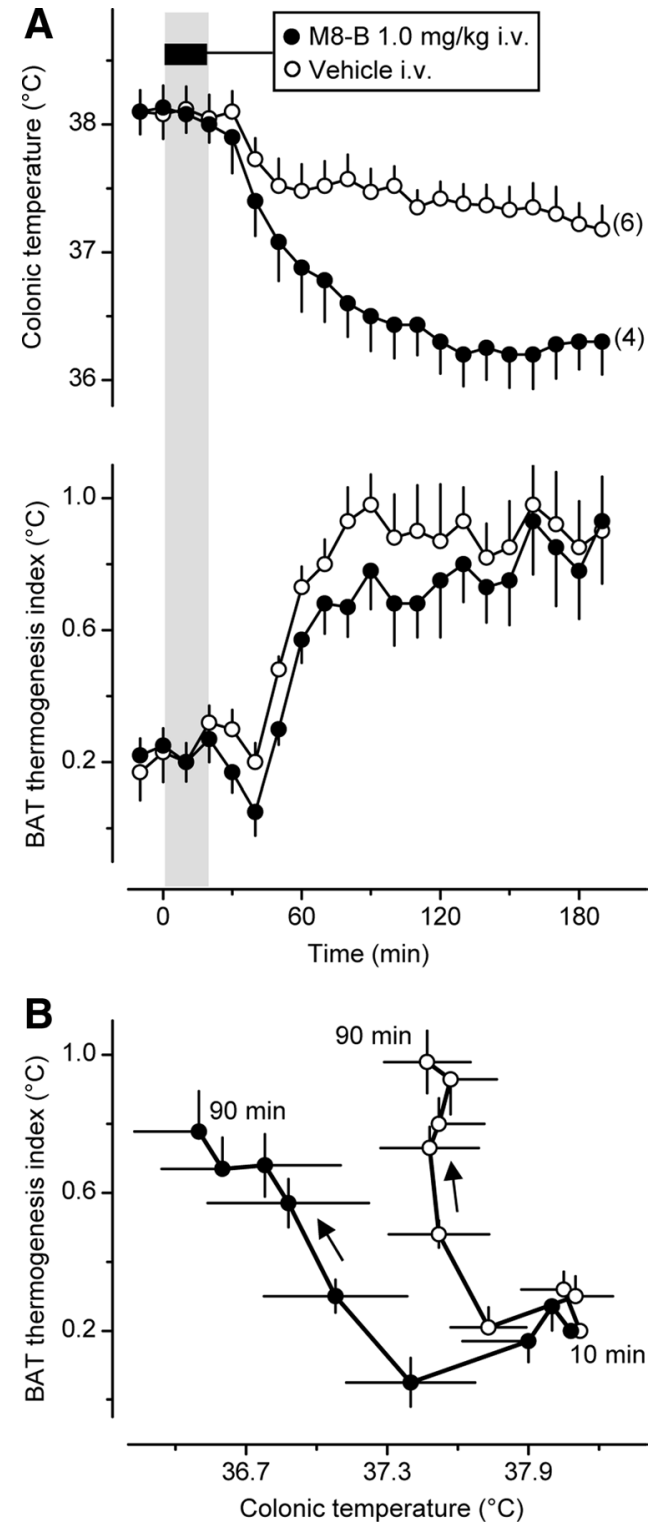

Figure 10. Nonshivering thermogenesis in BAT is suppressed at onset of the $T_{b}$ response to M8-B infusion and the subsequent cold exposure. Rats were infused with M8-B or its vehicle in a warm environment $\left(32^{\circ} \mathrm{C}\right)$ and transferred to a cold environment $\left(11^{\circ} \mathrm{C}\right)$ immediately thereafter (at $45 \mathrm{~min}$ ). $\boldsymbol{A}$, Changes in colonic $\mathrm{T}_{\mathrm{b}}$ and BAT thermogenesis. $\boldsymbol{B}$, Relationships between $B A T$ thermogenesis index and $\mathrm{T}_{\mathrm{b}}$ in M8-B-treated and vehicle-treated rats.

vasomotor tone (see Materials and Methods, Data processing and analysis). After infusion (when rats were transferred to $21^{\circ} \mathrm{C}$ ), both groups developed maximum tail-skin vasoconstriction (HLI, 0). However, the HLI decreased much faster in vehicle-treated rats than in M8-B-treated rats (Fig. $8 \mathrm{~A}$, inset), indicating that M8-B delayed the development of skin vasoconstriction by $\sim 5 \min (p=0.01)$. We then plotted the HLI against $\mathrm{T}_{\mathrm{b}}$ for the time period corresponding to the transition from vasodilation to vasoconstriction. As shown in Figure $8 B$, the constrictor response in M8-B-treated rats, in addition to being delayed in time, also occurred at a substantially lower deep $\mathrm{T}_{\mathrm{b}}(p=0.004)$. M8-B-treated rats continued to exhibit tail-skin vasodilation ( $\mathrm{HLI}, \sim 0.4$ ) when $\mathrm{T}_{\mathrm{b}}$ was $37.5^{\circ} \mathrm{C}$, whereas the controls were strongly vasoconstricted $(\mathrm{HLI}, \sim 0$ ) at this $\mathrm{T}_{\mathrm{b}}$. These data show that, at least in some cases, a lower tail-skin vasomotor tone contributes to the $\mathrm{T}_{\mathrm{b}}$ response to M8-B.
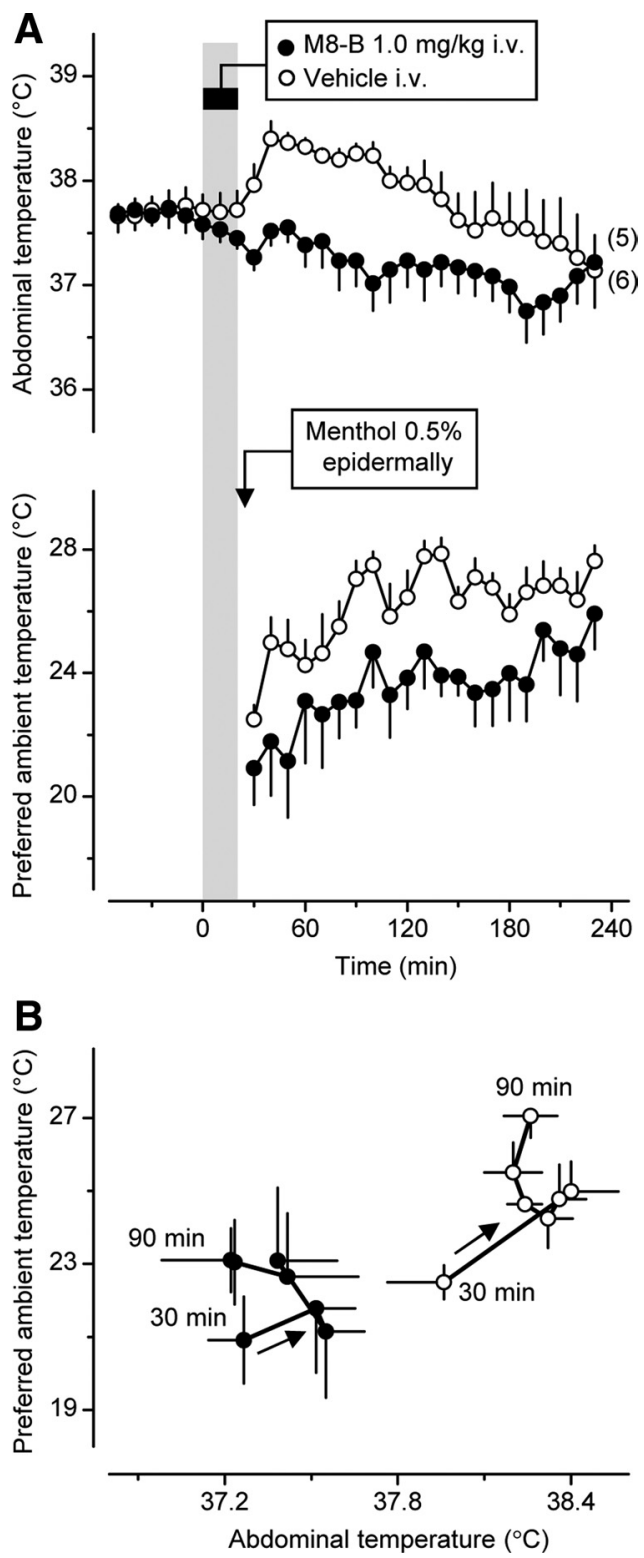

Figure 11. M8-B blocks the hyperthermic response and warmth-seeking behavior induced by menthol. After rats were infused intravenously with M8-B or its vehicle in a warm environment $\left(32^{\circ} \mathrm{C}\right)$, they were treated with menthol epidermally and released into a thermogradient apparatus, where they could select their preferred $T_{a} . A$, The effects of M8-B or its vehicle on deep (abdominal) $T_{b}$ and preferred $T_{a}$. $\boldsymbol{B}$, Relationships between preferred $T_{a}$ and $T_{b}$ in M8-Btreated and vehicle-treated rats during the first $60 \mathrm{~min}$ in the thermogradient.

M8-B-induced decrease in $T_{b}$ is accompanied by suppression of thermogenesis

We also studied whether $\mathrm{VO}_{2}$, a cumulative measure of shivering and nonshivering thermogenesis, was suppressed by M8-B. Because we could not transfer rats from one climatic chamber to another while continually measuring $\mathrm{VO}_{2}$, these experiments were conducted in the respirometry setup at a constant subneutral $\mathrm{T}_{\mathrm{a}}\left(19^{\circ} \mathrm{C}\right)$, without changing climatic chambers. Rats were infused with the high dose of M8-B ( $6 \mathrm{mg} / \mathrm{kg}$, i.v.) or vehicle over $20 \mathrm{~min}$ (as in Fig. $2 \mathrm{~A}$ ), and their $\mathrm{T}_{\mathrm{b}}$ and $\mathrm{VO}_{2}$ were measured. During the entire experiment, vehicle-infused rats maintained body temperatures at $37.2-37.3^{\circ} \mathrm{C}$ and had $V \mathrm{O}_{2}$ values of $\sim 18-21 \mathrm{ml} / \mathrm{kg} / \mathrm{min}$ (Fig. $9 A$ ). In contrast, M8-B-treated rats decreased $\mathrm{T}_{\mathrm{b}}$ and $V \mathrm{O}_{2}$ from $\sim 37.3^{\circ} \mathrm{C}$ and $19 \mathrm{ml} / / \mathrm{kg} / \mathrm{min}$ to $\sim 36.5^{\circ} \mathrm{C}$ and $15 \mathrm{ml} / \mathrm{kg} / \mathrm{min}$, respectively $(p<0.0001$ for both 


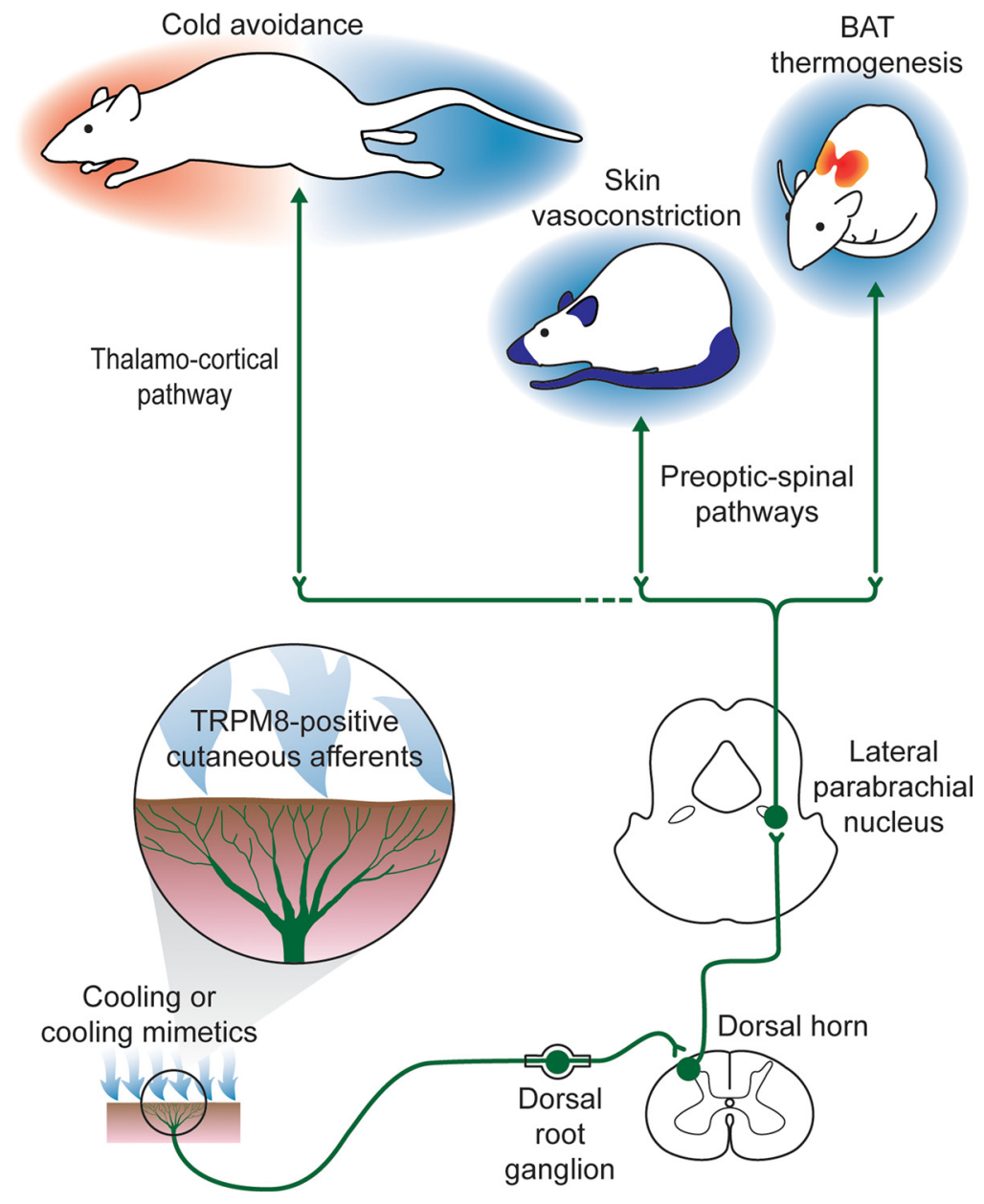

Figure 12. Cutaneous TRPM8 controls autonomic and behavioral thermoeffectors.

TRPM8 channels modulate selection of thermal environment

We then studied the effect of M8-B on thermoregulatory behavior. Rats were infused with M8-B (1 mg/kg, i.v.) in a warm environment $\left(32^{\circ} \mathrm{C}\right)$ and then transferred to the thermogradient apparatus, where they could move freely to select their preferred $\mathrm{T}_{\mathrm{a}}$. Even though M8-B-treated rats (compared to vehicle-treated rats) tended to select a lower $\mathrm{T}_{\mathrm{a}}$ for a short period immediately after transfer, no significant intertreatment differences were found in this experiment.

Because a more pronounced behavioral response to blockade of TRPM8 by M8-B can be expected when cutaneous TRPM8 channels are activated, we conducted another experiment, in which rats were treated with the TRPM8 agonist menthol (rats' abdomens were shaved before the experiment; see Materials and Methods, Anesthesia). Rats were infused with M8-B (1 mg/kg, i.v.) or its vehicle in a warm environment $\left(32^{\circ} \mathrm{C}\right)$. Immediately thereafter, they were treated epidermally with a premeasured quantity (10 g) of $0.5 \%$ menthol ointment (applied to the shaved abdominal skin) and transferred to the thermogradient apparatus. In agreement with previous findings (Almeida et al., 2006; Tajino et al., 2007), menthol-treated rats preinfused with vehicle increased thermopreferendum from $\sim 22$ to $\sim 27^{\circ} \mathrm{C}(p<0.0001)$ and developed a pronounced $\left(\sim 1^{\circ} \mathrm{C}\right)$ rise in $\mathrm{T}_{\mathrm{b}}$ $(p<0.0001)$ (Fig. 11A). Pretreatment

measurements), within the first hour after infusion. We then plotted $\mathrm{VO}_{2}$ against colonic $\mathrm{T}_{\mathrm{b}}$ (Fig. $9 \mathrm{~B}$ ). In this plot, data from vehicle-treated rats stayed within the same small area of the $V \mathrm{O}_{2}\left(\mathrm{~T}_{\mathrm{b}}\right)$ plane throughout the experiment, whereas data from M8-B-treated rats moved away from this area as the experiment progressed $(p=0.01)$. These results show that a depression of thermogenesis (whether shivering or nonshivering) is involved in the hypothermic response to M8-B.

\section{M8-B suppresses nonshivering thermogenesis in BAT}

To assess nonshivering thermogenesis in BAT specifically, we measured $\mathrm{T}_{\mathrm{BAT}}$ and, as in the past (Romanovsky et al., 1997), used the difference between $\mathrm{T}_{\mathrm{BAT}}$ and colonic $\mathrm{T}_{\mathrm{b}}$ as a BAT thermogenesis index. To produce a large drop in $\mathrm{T}_{\mathrm{b}}$ (and presumably a strong activation of BAT thermogenesis), this experiment was conducted exactly as the one shown in Figure $6 \mathrm{H}$, except that $\mathrm{T}_{\mathrm{BAT}}$ was also measured. After vehicle-treated rats were transferred to the cold $\left(11^{\circ} \mathrm{C}\right)$, they initially decreased $\mathrm{T}_{\mathrm{b}}$ slightly $\left(\mathrm{by} \sim 0.3^{\circ} \mathrm{C}\right)$, but then mounted a strong thermogenic response (thermogenesis index of $\sim 1.0^{\circ} \mathrm{C}$ ), which largely prevented a further decrease in $\mathrm{T}_{\mathrm{b}}$ (Fig. $10 \mathrm{~A}$ ). In M8-B-treated rats, the thermogenic response to cold tended to be less pronounced ( $p=0.105$ ), and consequently, their $\mathrm{T}_{\mathrm{b}}$ continued to decrease until it reached a nadir of $\sim 36.2^{\circ} \mathrm{C}$ at $150 \mathrm{~min}$. The relationship between BAT thermogenesis and $\mathrm{T}_{\mathrm{b}}$ differed significantly in the two treatment groups $(p=0.012)$ (Fig. $10 B)$. These data show that M8-B affects $\mathrm{T}_{\mathrm{b}}$, at least in part, by suppressing the thermogenic activity in BAT. with $\mathrm{M} 8$-B tended to attenuate the warmth-seeking response $(p=0.096)$ and significantly attenuated the hyperthermic response $(p=0.0009)$ to menthol. Furthermore, when preferred $\mathrm{T}_{\mathrm{a}}$ was plotted against $\mathrm{T}_{\mathrm{b}}$ for M8-B-pretreated rats and vehiclepretreated rats (Fig. $11 \mathrm{~B}$ ), the two pretreatment groups occupied significantly distinct areas $(p=0.017)$. This experiment shows that TRPM8-mediated signals are involved in the control of behavioral thermoregulatory responses. This conclusion is in agreement with the reported suppression of cold-avoidance behavior in Trpm $8^{-/-}$mice (Bautista et al., 2007; Colburn et al., 2007; Dhaka et al., 2007).

\section{Discussion}

Whereas it has been shown definitively that TRPM8 channels mediate the avoidance of innocuous cold (Bautista et al., 2007; Colburn et al., 2007; Dhaka et al., 2007), it is unknown whether TRPM8-mediated signals from the skin are essential for the regulation of deep $\mathrm{T}_{\mathrm{b}}$. It has also been unknown whether any thermoregulatory effectors (other than cold-avoidance behavior) are controlled by TRPM8-mediated cutaneous cold signals. The development of selective TRPM8 antagonists has been anticipated and widely expected to provide new insights into the role of the TRPM8 channel (McCoy et al., 2011). The present work meets some of these expectations. By studying the physiological effects of a selective and potent TRPM8 antagonist (and by excluding its off-target action with experiments in $\operatorname{Trpm} 8^{-/-}$mice), we have 
shown that deep $\mathrm{T}_{\mathrm{b}}$ depends on cold signals from cutaneous TRPM8 channels.

The present results also suggest that TRPM8 channels are universal cold detectors in the skin, in the sense that they control all of the main cold defenses (at least in rodents): cold-avoidance behavior, tail-skin vasoconstriction, and nonshivering thermogenesis in BAT (Fig. 12). Such a universal role of TRPM8 on skin afferents agrees well with many thermophysiological and electrophysiological studies showing that most skin thermoreceptors are cold sensitive (Jessen, 1985; Nomoto et al., 2004) and that $\mathrm{T}_{\text {sk }}$ signals make substantial contributions to the control of most thermoeffectors (Jessen, 1981; Roberts, 1988; Sakurada et al., 1993; Bratincsak and Palkovits, 2005; Tanaka et al., 2006; Nakamura and Morrison, 2007). The recent finding by Teliban et al. (2011) is also of interest. These authors reported that coldsensitive cutaneous nerves of what Janig et al. (2009) call type 1 (presumably TRPM8 expressing) respond to innocuous cold applied not only to nerve terminals, but also to portions of axons at a distance from the terminals. Hence, a picture emerges, according to which TRPM8 channels on terminals and axons of nerves that form a dense network in the skin are activated by innocuous cold to control multiple autonomic and behavioral thermoeffectors. While this report was in preparation, Tajino et al. (2011) published a study in $\operatorname{Trpm} 8^{-1-}$ mice describing altered thermoeffector responses in these animals. In our opinion, the study by Tajino et al. (2011) supports our conclusion that TRPM8 controls both behavioral and autonomic thermoeffectors, even though the authors of that study interpreted their results somewhat differently.

The present work also demonstrates that blocking cold signaling from the skin by a TRPM8 antagonist can inactivate cold defenses and decrease deep $T_{b}$ in an unanesthetized organism. While the present paper was in revision, Knowlton et al. (2011) reported that a different TRPM8 antagonist also caused hypothermia in mice. Because the present study shows that the hypothermic response to M8-B strongly depended on $\mathrm{T}_{\mathrm{a}}$, the TRPM8-antagonist-induced hypothermia is the first example of a change in the deep $\mathrm{T}_{b}$ of an animal occurring as a result of pharmacological blockade of specific thermal signals at the thermoreceptor level. TRPV1 antagonists have also been reported to affect $\mathrm{T}_{\mathrm{b}}$ (to cause hyperthermia), but their effect results from blocking nonthermal activation of TRPV1 channels (Steiner et al., 2007). We believe that the principle demonstrated in the present work-selective pharmacological modulation of thermoreception - will be used in the future to induce mild therapeutic hypothermia in unanesthetized patients and, in general, to maintain deep $T_{b}$, and perhaps the activity of some thermoeffectors, at desired levels. A new discipline, thermopharmacology, is emerging.

\section{Notes}

Supplemental material for this article is available at http://www.feverlab.net/ pages/publicationpdfs/supplementJN2012.pdf. Supplemental Figure 1 shows changes in cellular $\mathrm{Ca}^{2+}$ in response to cold, menthol, and $\mathrm{KCl}$ in murine sensory neurons in the absence or presence of M8-B. Supplemental Figure 2 shows colonic $\mathrm{T}_{\mathrm{b}}$ responses of rats to intravenous or intrathecal M8-B $(6 \mathrm{mg} / \mathrm{kg})$ at a constant subneutral $\mathrm{T}_{\mathrm{a}}$ of $19^{\circ} \mathrm{C}$. Supplemental Figure 3 shows effects of M8-B ( $1 \mathrm{mg} / \mathrm{kg}$, i.v.) on the abdominal $\mathrm{T}_{\mathrm{b}}$ and preferred $\mathrm{T}_{\mathrm{a}}$ of rats in a thermogradient $\left(15-30^{\circ} \mathrm{C}\right)$. This material has not been peer reviewed.

\section{References}

Almeida MC, Steiner AA, Branco LG, Romanovsky AA (2006) Cold-seeking behavior as a thermoregulatory strategy in systemic inflammation. Eur J Neurosci 23:3359-3367.
Bachtell RK, Tsivkovskaia NO, Ryabinin AE (2003) Identification of temperature-sensitive neural circuits in mice using c-Fos expression mapping. Brain Res 960:157-164.

Bautista DM, Siemens J, Glazer JM, Tsuruda PR, Basbaum AI, Stucky CL, Jordt SE, Julius D (2007) The menthol receptor TRPM8 is the principal detector of environmental cold. Nature 448:204-208.

Bernard SA, Gray TW, Buist MD, Jones BM, Silvester W, Gutteridge G, Smith K (2002) Treatment of comatose survivors of out-of-hospital cardiac arrest with induced hypothermia. N Engl J Med 346:557-563.

Boulant JA (2006) Counterpoint: Heat-induced membrane depolarization of hypothalamic neurons: an unlikely mechanism of central thermosensitivity. Am J Physiol 290:R1481-R1484; discussion R1484.

Bratincsak A, Palkovits M (2004) Activation of brain areas in rat following warm and cold ambient exposure. Neuroscience 127:385-397.

Bratincsak A, Palkovits M (2005) Evidence that peripheral rather than intracranial thermal signals induce thermoregulation. Neuroscience 135:525-532.

Bratincsak A, Kovacs ZI, Palkovits M (2008) Direct neuronal projection from a brainstem thermosensitive cell group to the preoptic thermoregulatory center. Neuroscience 156:966-972.

Cechetto DF, Standaert DG, Saper CB (1985) Spinal and trigeminal dorsal horn projections to the parabrachial nucleus in the rat. J Comp Neurol 240:153-160.

Colburn RW, Lubin ML, Stone DJ, Jr., Wang Y, Lawrence D, D’Andrea MR, Brandt MR, Liu Y, Flores CM, Qin N (2007) Attenuated cold sensitivity in TRPM8 null mice. Neuron 54:379-386.

Conti B, Sanchez-Alavez M, Winsky-Sommerer R, Morale MC, Lucero J, Brownell S, Fabre V, Huitron-Resendiz S, Henriksen S, Zorrilla EP, de Lecea L, Bartfai T (2006) Transgenic mice with a reduced core body temperature have an increased life span. Science 314:825-828.

Dhaka A, Murray AN, Mathur J, Earley TJ, Petrus MJ, Patapoutian A (2007) TRPM8 is required for cold sensation in mice. Neuron 54:371-378.

Feil K, Herbert H (1995) Topographic organization of spinal and trigeminal somatosensory pathways to the rat parabrachial and Kolliker-Fuse nuclei. J Comp Neurol 353:506-528.

Garami A, Shimansky YP, Pakai E, Oliveira DL, Gavva NR, Romanovsky AA (2010) Contributions of different modes of TRPV1 activation to TRPV1 antagonist-induced hyperthermia. J Neurosci 30:1435-1440.

Garami A, Pakai E, Oliveira DL, Steiner AA, Wanner SP, Almeida MC, Lesnikov VA, Gavva NR, Romanovsky AA (2011) Thermoregulatory phenotype of the Trpvl knockout mouse: thermoeffector dysbalance with hyperkinesis. J Neurosci 31:1721-1733.

Gavva NR, Tamir R, Qu Y, Klionsky L, Zhang TJ, Immke D, Wang J, Zhu D, Vanderah TW, Porreca F, Doherty EM, Norman MH, Wild KD, Bannon AW, Louis JC, Treanor JJ (2005) AMG 9810 [(E)-3-(4-t-butylphenyl)$N$-(2,3-dihydrobenzo[b] [1,4] dioxin-6-yl)acrylamide], a novel vanilloid receptor 1 (TRPV1) antagonist with antihyperalgesic properties. J Pharmacol Exp Ther 313:474-484.

Janig W, Grossmann L, Gorodetskaya N (2009) Mechano- and thermosensitivity of regenerating cutaneous afferent nerve fibers. Exp Brain Res 196:101-114.

Jessen C (1981) Independent clamps of peripheral and central temperatures and their effects on heat production in the goat. J Physiol 311:11-22.

Jessen C (1985) Thermal afferents in the control of body temperature. Pharmacol Ther 28:107-134.

Knowlton WM, Daniels RL, Palkar R, McCoy DD, McKemy DD (2011) Pharmacological blockade of TRPM8 ion channels alters cold and cold pain responses in mice. PLoS One 6:e25894.

Lampe T, Alonso-Alija C, Stelte-Ludwig B, Sandner P, Bauser M, Beck H, Lustig K, Rosentreter U, Stahl E (2006) Substituted 4-benzyloxyphenylmethylamide derivatives as cold menthol receptor-1 (CMR-1) antagonists for the treatment of urological disorder. World Intellectual Property Organization, International Publication Number WO 2006/ $040136 \mathrm{~A} 1$.

Lehto SG, Tamir R, Deng H, Klionsky L, Kuang R, Le A, Lee D, Louis JC, Magal E, Manning BH, Rubino J, Surapaneni S, Tamayo N, Wang T, Wang J, Wang J, Wang W, Youngblood B, Zhang M, Zhu D, Norman MH, Gavva NR (2008) Antihyperalgesic effects of $(R, E)-N$-(2-hydroxy-2,3-dihydro- $1 \mathrm{H}$ inden-4-yl)-3-(2-(piperidin-1-yl)-4-(trifluoromethyl)phenyl)-acrylamide (AMG8562), a novel transient receptor potential vanilloid type 1 modulator that does not cause hyperthermia in rats. J Pharmacol Exp Ther 326:218-229. Le Poul E, Hisada S, Mizuguchi Y, Dupriez VJ, Burgeon E, Detheux M (2002) 
Adaptation of aequorin functional assay to high throughput screening. J Biomol Screen 7:57-65.

Lumpkin EA, Caterina MJ (2007) Mechanisms of sensory transduction in the skin. Nature 445:858-865.

McAllen RM, Tanaka M, Ootsuka Y, McKinley MJ (2010) Multiple thermoregulatory effectors with independent central controls. Eur J Appl Physiol 109:27-33.

McCoy DD, Knowlton WM, McKemy DD (2011) Scraping through the ice: Uncovering the role of TRPM8 in cold transduction. Am J Physiol 300:R1278-R1287.

McKemy DD, Neuhausser WM, Julius D (2002) Identification of a cold receptor reveals a general role for TRP channels in thermosensation. Nature 416:52-58.

Mishra SK, Tisel SM, Orestes P, Bhangoo SK, Hoon MA (2011) TRPV1lineage neurons are required for thermal sensation. EMBO J 30:582-593.

Nakamura K, Morrison SF (2007) Central efferent pathways mediating skin cooling-evoked sympathetic thermogenesis in brown adipose tissue. Am J Physiol 292:R127-R136.

Nakamura K, Morrison SF (2008) A thermosensory pathway that controls body temperature. Nat Neurosci 11:62-71.

Nomoto S, Shibata M, Iriki M, Riedel W (2004) Role of afferent pathways of heat and cold in body temperature regulation. Int J Biometeorol 49:67-85.

Paxinos G, Watson C (2007) The rat brain in stereotaxic coordinates, Ed 6. San Diego: Academic.

Peier AM, Moqrich A, Hergarden AC, Reeve AJ, Andersson DA, Story GM, Earley TJ, Dragoni I, McIntyre P, Bevan S, Patapoutian A (2002) A TRP channel that senses cold stimuli and menthol. Cell 108:705-715.

Pogatzki EM, Zahn PK, Brennan TJ (2000) Lumbar catheterization of the subarachnoid space with a 32-gauge polyurethane catheter in the rat. Eur J Pain 4:111-113.

Roberts WW (1988) Differential thermosensor control of thermoregulatory grooming, locomotion, and relaxed postural extension. Ann N Y Acad Sci 525:363-374.

Romanovsky AA (2007) Thermoregulation: some concepts have changed. Functional architecture of the thermoregulatory system. Am J Physiol 292:R37-R46.

Romanovsky AA, Shido O, Sakurada S, Sugimoto N, Nagasaka T (1996) Endotoxin shock: thermoregulatory mechanisms. Am J Physiol 270: R693-R703.

Romanovsky AA, Kulchitsky VA, Simons CT, Sugimoto N, Szekely M (1997) Cold defense mechanisms in vagotomized rats. Am J Physiol 273:R784R789.

Romanovsky AA, Ivanov AI, Shimansky YP (2002) Selected contribution: ambient temperature for experiments in rats: a new method for determining the zone of thermal neutrality. J Appl Physiol 92:2667-2679.

Romanovsky AA, Almeida MC, Garami A, Steiner AA, Norman MH, Morrison SF, Nakamura K, Burmeister JJ, Nucci TB (2009) The transient receptor potential vanilloid-1 channel in thermoregulation: a thermosensor it is not. Pharmacol Rev 61:228-261.

Rudaya AY, Steiner AA, Robbins JR, Dragic AS, Romanovsky AA (2005) Thermoregulatory responses to lipopolysaccharide in the mouse: depen- dence on the dose and ambient temperature. Am J Physiol 289: R1244-R1252.

Sagar SM, Sharp FR, Curran T (1988) Expression of c-fos protein in brain: metabolic mapping at the cellular level. Science 240:1328-1331.

Sakurada S, Shido O, Fujikake K, Nagasaka T (1993) Relationship between body core and peripheral temperatures at the onset of thermoregulatory responses in rats. Jpn J Physiol 43:659-667.

Shankaran S, Laptook AR, Ehrenkranz RA, Tyson JE, McDonald SA, Donovan EF, Fanaroff AA, Poole WK, Wright LL, Higgins RD, Finer NN, Carlo WA, Duara S, Oh W, Cotten CM, Stevenson DK, Stoll BJ, Lemons JA, Guillet R, Jobe AH (2005) Whole-body hypothermia for neonates with hypoxic-ischemic encephalopathy. N Engl J Med 353:1574-1584.

Steiner AA, Turek VF, Almeida MC, Burmeister JJ, Oliveira DL, Roberts JL, Bannon AW, Norman MH, Louis JC, Treanor JJ, Gavva NR, Romanovsky AA (2007) Nonthermal activation of transient receptor potential vanilloid-1 channels in abdominal viscera tonically inhibits autonomic cold-defense effectors. J Neurosci 27:7459-7468.

Steiner AA, Hunter JC, Phipps SM, Nucci TB, Oliveira DL, Roberts JL, Scheck AC, Simmons DL, Romanovsky AA (2009) Cyclooxygenase-1 or -2which one mediates lipopolysaccharide-induced hypothermia? Am J Physiol 297:R485-R494.

Steiner AA, Molchanova AY, Dogan MD, Patel S, Petervari E, Balasko M, Wanner SP, Eales J, Oliveira DL, Gavva NR, Almeida MC, Szekely M, Romanovsky AA (2011) The hypothermic response to bacterial lipopolysaccharide critically depends on brain CB1, but not CB2 or TRPV1, receptors. J Physiol 589:2415-2431.

Tajino K, Matsumura K, Kosada K, Shibakusa T, Inoue K, Fushiki T, Hosokawa H, Kobayashi S (2007) Application of menthol to the skin of whole trunk in mice induces autonomic and behavioral heat-gain responses. Am J Physiol 293:R2128-R2135.

Tajino K, Hosokawa H, Maegawa S, Matsumura K, Dhaka A, Kobayashi S (2011) Cooling-sensitive TRPM8 is thermostat of skin temperature against cooling. PLoS One 6:e17504.

Takashima Y, Daniels RL, Knowlton W, Teng J, Liman ER, McKemy DD (2007) Diversity in the neural circuitry of cold sensing revealed by genetic axonal labeling of transient receptor potential melastatin 8 neurons. J Neurosci 27:14147-14157.

Talavera K, Nilius B, Voets T (2008) Neuronal TRP channels: thermometers, pathfinders and life-savers. Trends Neurosci 31:287-295.

Tanaka M, Owens NC, Nagashima K, Kanosue K, McAllen RM (2006) Reflex activation of rat fusimotor neurons by body surface cooling, and its dependence on the medullary raphe. J Physiol 572:569-583.

Teliban A, Bartsch F, Struck M, Baron R, Janig W (2011) Axonal thermosensitivity and mechanosensitivity of cutaneous afferent neurons. Eur J Neurosci 33:110-118.

van der Worp HB, van Gijn J (2007) Clinical practice. Acute ischemic stroke. N Engl J Med 357:572-579.

Werner J (2010) System properties, feedback control and effector coordination of human temperature regulation. Eur J Appl Physiol 109:13-25.

Zhao Y, Boulant JA (2005) Temperature effects on neuronal membrane potentials and inward currents in rat hypothalamic tissue slices. J Physiol 564:245-257. 